1 Study of the planetary boundary layer height in an urban

2 environment using a combination of microwave

3 radiometer and ceilometer

4

5 Gregori de Arruda Moreira, Juan Luis Guerrero-

6 Rascado, Juan Antonio Bravo-Aranda, Inmaculada Foyo-

7 Moreno, Alberto Cazorla, Inmaculada Alados, Hassan

8 Lyamani, Eduardo Landulfo, Lucas Alados-Arboledas

9

10 Atmospheric Research

11 Volume 240, August 2020, 104932

12 https://doi.org/10.1016/j.atmosres.2020.104932 


\section{Study of the Planetary Boundary Layer Height in an urban 2 environment using a combination of microwave radiometer 3 and ceilometer}

4 Gregori de Arruda Moreira ${ }^{1,2,3}$, Juan Luis Guerrero-Rascado ${ }^{1,2}$, Juan Antonio Bravo5 Aranda $^{1,2}$, Inmaculada Foyo-Moreno ${ }^{1,2}$, Alberto Cazorla ${ }^{1,2}$, Inmaculada Alados ${ }^{1,4}$, Hassan 6 Lyamani $^{1,2}$, Eduardo Landulfo ${ }^{3}$ and Lucas Alados-Arboledas ${ }^{1,2}$

$7 \quad{ }^{1}$ Andalusian Institute for Earth System Research (IISTA-CEAMA), Granada, Spain

$8 \quad{ }^{2}$ Dpt. Applied Physics, University of Granada, Granada, Spain

$9 \quad{ }^{3}$ Institute of Research and Nuclear Energy (IPEN), São Paulo, Brazil

$10 \quad{ }^{4}$ Dpt. Applied Physics II, University of Malaga, Spain

11 Correspondence to: Gregori de Arruda Moreira (gregori.moreira@usp.br)

Keywords Planetary Boundary Layer, Ceilometer, Microwave Radiometer, Remote Sensing

\section{Abstract}

The Planetary Boundary Layer $(P B L)$ is an important part of the atmosphere that is relevant in different atmospheric fields like pollutant dispersion, and weather forecasting. In this study, we analyze four and five-year datasets of measurements gathered with a ceilometer and a microwave radiometer to study the PBL structure respectively, in the mid-latitude urban area of Granada (Spain). The methodologies applied for the PBL Height (PBLH) detection (gradient method for ceilometer and the combination of parcel method and temperature gradient method for microwave radiometer) provided a description in agreement with the literature about the $P B L$ structure under simple scenarios. Then, the $P B L H$ behavior is characterized by a statistical study of the convective and stable situations, so that the $P B L H$ was obtained from microwave radiometer measurements. The analysis of the $P B L H$ statistical study shows some agreement with other $P B L H$ studies such as daily pattern and yearly cycle, and the discrepancies were explained in terms of distinct latitudes, topography and climate conditions. Finally, it was performed a joint long-term analysis of the residual layer $(R L)$ provided by ceilometer and the stable and convective layer heights determined by microwave radiometer, offering a complete picture of the $P B L$ evolution by synergetic combination of remote sensing techniques. The $P B L$ behavior has been used for explaining the daily cycle of Black Carbon $(B C)$ concentration, used as tracer of the pollutants emissions associated to traffic.

\section{Introduction}

The planetary boundary layer $(P B L)$ is traditionally defined as the "part of the troposphere that is directly influenced by the presence of the Earth's surface, and responds to surface forcings with a time scale of about an hour or less" (Stull, 1988). Under an ideal scenario, shortly after sunrise the positive net radiative flux $\left(R_{n}\right)$ causes the rising of ground surface temperature. Consequently, air masses located at low heights get warmer and favor convective processes, which lead to air lifting and consequent heating of atmospheric layers at a certain altitude over the surface inside the troposphere. The new layer generated by this mechanism is known as convective boundary layer $(C B L)$ or mixing layer $\left(M_{\text {ing }} L\right)$. After sometime this 
layer might get completely well-mixed and it is known as mixed layer $\left(M_{e d} L\right)$. Close to sunset, the $C B L$ is converted in a stably stratified boundary layer called residual layer $(R L)$ that contains features from the $M_{\text {ing }} L$ ( or $M_{e d} L$ ) of the previous day. Simultaneously, a thermal inversion appears close to surface and the stable region extending from surface to the thermal inversion is usually named stable boundary layer $(S B L)$. The height of $P B L(P B L H)$ is an important parameter that characterizes the $P B L$ structure and provides information on the vertical extent of mixing within this layer as well as the vertical dispersion and convective transport. The $P B L H$ is a key factor for a wide set of studies, such as air quality, pollutant dispersion, weather forecasting and meteorological modeling (e.g. Chen et. al., 2011). However, it is not possible to obtain this variable in a straightforward way, being necessary to infer it from radiosonde data, remote sensing systems or meteorological models. In this sense, in the last decades a great effort has been made to develop other methods for inferring $P B L H$ with high temporal and spatial resolution from remote sensing systems such as lidar and ceilometer (e.g. Bianco et al., 2005; Eresma et al., 2006; He et al., 2006; Münkel et al.,2007; Di Giuseppe et al.,2012; Granados-Muñoz et al., 2012; Di Giuseppe et al., 2012; Haman et al., 2012; Pal et al., 2013; Coen et al., 2014; Korhonen et al., 2014; Ketterer et al., 2014; Lotteraner et al.,2016; Zhu et al.,2016; Uzan et al.,2016; Avolio et al., 2017; Caicedo et al., 2017; de Arruda Moreira et al., 2018; Zhu et al., 2018a; Zhu et al., 2018b; de Arruda Moreira et al., 2019), because their high temporal and spatial resolution enable a better comprehension on the daily cycle of $P B L$.

Ceilometers provide the $P B L H$ from vertical aerosol profiles based on the Deadorff's definition of $M_{\text {ing }} L$ ( or $M_{e d} L$ ), which is the "height where there are equal areas of clear air above and particulates below" (Deadorff et al., 1980). Therefore, the PBLH "is taken to be the midpoint of the transition region between the areas of higher and lower backscattering", i.e. the top of aerosol layer. Thus, when $P B L$ is fully developed the height of $C B L\left(C B L H_{\text {Ceilometer }}\right)$ is detected; otherwise the $R L$ height $\left(R L_{\text {Ceilometer }}\right)$ is observed. Although ceilometers and aerosol lidars have similar operating principles, ceilometers have some advantages, such as relatively continuous operations and low-maintenance, eye-safe and comparatively low price, which compensates the disadvantages of lower maximum range and relatively low signal-to-noise ratio $(S N R)$. These facts justify their increasing use in studies related to PBLH(e.g. Eresma et al., 2006; Münkel et al.,2007; Di Giuseppe et al.,2012; Ketterer et al., 2014; Lotteraner et al.,2016; Zhu et al.,2016; Uzan et al.,2016; Avolio et al., 2017; Caicedo et al., 2017; Zhu et al., 2018a; Zhu et al., 2018b).

While most of remote sensing systems have their data acquisition affected by rain and cloud covers, the Microwave Radiometers (MWR) measurements are not influenced by these factors (Kim et al., 2015). This behavior allows continuous (24/7) and autonomous operation with a high data recovery rate, making the $M W R$ as an important tool for $P B L$ characterization by determining liquid water path (Van Baelen et al., 2005), brightness temperature (Cimini et al., 2013), atmospheric stability (Arend et al., 2016), and nowcasting convective weather (Cimini et al., 2015). Bedoya-Velázquez et al. (2019) performed a validation of $M W R$ data comparing them with 5 years of radiosonde data at Granada-Spain. Such analysis demonstrated as $M W R$ profiles of temperature and humidity are reliable. Zhao et al. (2019) also confirmed the reliability of $M W R$ data, mainly at the lower troposphere $(<2000 \mathrm{~m})$, comparing them with radiosonde data. $M W R$ also have been used in synergy with other remote sensing instruments (e.g. Bianco et al., 2005; 
with those provided by other remote sensing systems, such as elastic (e.g. Muñoz-Granados et al., 2012; Bravo-Aranda et al., 2017) and Doppler lidar (de Arruda Moreira et al., 2018), so that, in convective situations, a high concordance can be observed among them. In addition, $M W R$ has null overlap and it does not use aerosols as tracer, what enables to detect the $S B L$. On the other hand, $M W R$ has as disadvantage a lower vertical resolution in comparison with lidar systems and ceilometers.

Remote sensing systems have been mainly applied to study the $P B L$ in periods between several months and one year (e.g. He et al., 2006; Granados-Muñoz et al., 2012; Di Giuseppe et al., 2012; Haman et al., 2012; Pal et al., 2013; Korhonen et al., 2014; Schween et al., 2014). Only few of them use multi-year data (Coen et al., 2014; Pal et al., 2015; Zhu et al., 2018a; Zhu et al., 2018b), allowing a better comprehension about seasonality, interannual variability and how some variables can influence the PBLH. However, due to technical limitations of each instrument (ceilometer incomplete overlap, signal to noise ratio and spatial resolution, among others), some phenomena such as the evolution from $C B L$ towards the combination of the $S B L$ and $R L$ close to sunset or, for example, or the rising of the $C B L$ until breaking the $R L$ along the morning, cannot be properly detected. In contrast, the synergistic use of remote sensing systems can provide complementary information and enable a more detailed observation of PBL.

In this regard, this work presents a statistical analysis of the $P B L$ obtained from 4 and 5 year database of ceilometer and $M W R$ measurements, respectively, performed at Granada (Spain). Our synergic analyses have in mind that the PBLH retrievals by these two different instruments are based on the use of different observed quantities (aerosol backscatter and temperature vertical profiles) which offer complementary picture of the $P B L$ structure, due to distinct $P B L H$ definition applied to each one.

The $P B L$ structure affect the concentrations of the different air pollutants at surface level. Among different atmospheric pollutants, Black Carbon $(B C)$ has become a matter of concern during the past years due to its adverse human health effects, being a primary product of incomplete combustion of carbonaceous fuels, normally originated from diesel engines in urban areas (e.g. Hamilton and Mansfield, 1991; Pakkanen et al., 2000; Titos et al., 2017). $B C$ is a more consistent tracer than ultrafine particles (UFP) to analyse the links between $P B L$ and air pollution at an urban site, since $B C$ is a passive atmospheric component that undergoes less transformation in the atmosphere. Recently, Petäjäet al. (2016) and Ding et al., (2016) showed that high $B C$ concentrations result in low boundary layer height which lead to elevated aerosol concentrations and significantly degraded air quality. However, the relationship between $B C$ concentration and $P B L$ is still ambiguous and more studies in different areas are needed to better understand the links between $B C$ and $P B L$. Thus, in this study we also analyzed the $B C$ concentration and its link to $P B L$ behavior at Granada.

This paper is organized as follows. Description of the experimental site and the equipment setup are presented in Section 2. The methodologies applied are introduced in Section 3. A long-term analysis is carried out in Section 4. Conclusions are given in Section 5. 
2 The measurement campaign was carried out at the Andalusian Institute of Earth System Research (IISTA3 CEAMA). This station is part of European Aerosol Research Lidar Network - EARLINET (Pappalardo et 4 al., 2014) since 2004 and at present is an active station of ACTRIS (http://actris2.nilu.no/). This station is 5 located at Granada, a medium sized (population of around 238000 inhabitants over an area of $88 \mathrm{~km}^{2}$ ) non6 industrialized city in the Southeastern Spain at about $50 \mathrm{~km}$ away from the Mediterranean coast (Granada, $737.16^{\circ} \mathrm{N}, 3.61^{\circ} \mathrm{W}, 680 \mathrm{~m}$ a.s.l.) (INE, 2017). Granada is surrounded by mountains and dominated by 8 Mediterranean-continental conditions, which are responsible for large seasonal temperature differences, providing cool winters and hot summers. The most humid period goes from late autumn to early spring. The rest of the year is characterized by rain scarcity. It is worthy to note that the Southeastern Spain is usually affected by mineral dust outbreaks from the Saharan Desert (North Africa) (e.g. Lyamani et al., 2006a, b; Guerrero-Rascado et al., 2008a, 2009; Granados-Muñoz et al., 2010; Córdoba-Jabonero et al., 2011; Titos et al., 2012; Navas-Guzmán et al., 2013; Valenzuela et al., 2014; Bravo-Aranda et al., 2017), which may affect the $P B L$ detection. Main local sources of aerosol particles are road traffic, domesticheating and biomass burning (mostly in winter time) (Titos et al., 2017, Patrón et al., 2017). Transported smoke principally from North America, North Africa and the Iberian Peninsula can also affect the study area (Alados-Arboledas et al., 2011; Pereira et al., 2013; Navas-Guzmán et al., 2013; Preißler et al., 2013; Pereira et al., 2014; Ortiz-Amezcua et al., 2014, 2017).

The measurements were performed from two kind of remote sensing systems, namely passive and active ones. The passive remote sensing systems measures the energy naturally available, e.g. passive microwave radiometer, which measures the sky brightness temperature. Active remote sensing systems emits radiation toward the target to be investigated. Such radiation is reflected from the target and detected back by the remote system sensors, e. g. ceilometer emits a laser beam what is backscattered by atmospheric molecules, aerosols and/or clouds, and posteriorly detected by the system.

The ground-based passive microwave radiometer (RPG-HATPRO G2, Radiometer Physics GmbH) is situated at IISTA-CEAMA and it is part of the MWRnet [http://cetemps.aquila.infn.it/mwrnet/] (Rose et al., 2005; Caumont et al., 2016). It has been operating in the scanning mode in automatic and continuous mode since November 2011. The MWR measures the sky brightness temperature with a radiometric resolution between 0.3 and $0.4 \mathrm{~K}$ root mean square error at $1 \mathrm{~s}$ integration time and uses direct detection receivers within two bands: $22-31 \mathrm{GHz}$ (water vapor - $\mathrm{K}$ band) and $51-58 \mathrm{GHz}$ (oxygen - V band), which are used for deriving relative humidity and temperature profiles, respectively. Relative humidity $(R H)$ and temperature profiles from brightness temperature are obtained by inversion algorithms described in Rose et al. (2005). Due to the weighting functions of $M W R$ exponentially decrease with height (Spänkuch et al., 1996), both profiles (temperature and relative humidity) have a range resolution varying between 10 and $200 \mathrm{~m}$ in the first $2 \mathrm{~km}$ and varying between 200 and $1000 \mathrm{~m}$ up to $10 \mathrm{~km}$ (Navas-Guzmán et al., 2014). Its performance has been evaluated against a dataset of collocated radiosoundings (Bedoya-Velásquez et al., 2019). 
The ceilometer Jenoptik model CHM15k also was operated at the IISTA-CEAMA station. The system is part of the Iberian Ceilometer Network (ICENET), an initiative of the Atmospheric Physics Group of the University of Granada that coordinates a network combining ceilometers and Sun-photometers for the characterization of atmospheric aerosol with the objective of obtaining reliable vertically resolved aerosol optical properties in near real-time (Cazorla et al., 2017). It operates with a pulsed Nd:YAG laser emitting at $1064 \mathrm{~nm}$ and a telescope with a field of view of $0.45 \mathrm{mrad}$. The energy per pulse is $8.4 \mu \mathrm{J}$ with a repetition frequency in the range of 5-7 kHz. The laser beam divergence is less than $0.3 \mathrm{mrad}$. The spatial and temporal resolution used are $15 \mathrm{~m}$ and $15 \mathrm{~s}$, respectively (Cazorla et al., 2017). The complete overlap of the instrument is found around $1500 \mathrm{~m}$ above agl. The overlap is $90 \%$ complete at $555 \mathrm{~m}$ agl in accordance with overlap function provided by the manufacturer. This equipment has been operating continuously since December 2012.

$B C$ mass concentration was measured with a Multi-Angle Absorption Photometer (MAAP) (Thermo ESM Andersen Instruments, Erlangen, Germany) operating by single-wavelength $(637 \mathrm{~nm})$ using a mass absorption of $6.6 \mathrm{~m}^{2} \mathrm{~g}^{-1}$ (Müller et al., 2011) with a time resolution of 1 minute (del Águila et al., 2018).

Meteorological variables, including ambient temperature $\left(T_{\text {air }}\right), R H$, horizontal wind speed $(v)$ and rainfall, were measured by an automatic weather station (HMP60, Vaisala) at IISTA-CEAMA. Data collected as 1 min averages were processed to calculate hourly means. $T_{\text {air }}$ is acquired with an accuracy and precision of $0.6^{\circ} \mathrm{C}$ and $0.01^{\circ} \mathrm{C}$, respectively. $R H$ is detected with an accuracy of $\pm 3 \%$. The ground-based station is equipped with a CM-11 pyranometer manufactured by Kipp \& Zonen (Delft, The Netherlands) measuring the SW solar irradiance data (310-3200 nm). The CM-11 pyranometer complies with the specifications for the first-class WMO classification of this instrument (resolution better than $\pm 5 \mathrm{~W} / \mathrm{m}^{2}$ ), and the calibration factor stability has been periodically checked against a reference CM-11 pyranometer (Alados-Arboledas et al., 1999).

All instruments described above are located on the IISTA-CEAMA terrace at approximately $12 \mathrm{~m}$ above the surface. The IISTA-CEAMA is surrounded by buildings with similar heights, so that the urban canopy influence on measurements (such as shades) is negligible.

\section{Methodology}

The PBLH detection by ceilometer $\left(P B L H_{\text {ceilometer }}\right)$ and $M W R\left(P B L H_{M W R}\right)$ are based on profiles of two different observed quantities, namely attenuated backscatter and temperature, respectively. The algorithms applied to each instrument are described below.

\subsection{MWR Method}

The algorithm applied to the $M W R$ combines two methodologies that are the parcel method (PM) and temperature gradient method (TGM), in order to detect the $P B L H_{M W R}$ in convective ( $\left.C B L H_{M W R}\right)$ and stable $\left(S B L H_{M W R}\right)$ situations, respectively. Firstly, the potential temperature profile $\theta(z)$ is derived from the temperature $T(z)$ profile provided by the $M W R$, using the following equation: 
2 where $z$ is the altitude above the sea level, and $0.0098 \mathrm{~K} / \mathrm{m}$ is the dry adiabatic lapse rate. The surface

3 potential temperature $\theta\left(z_{0}\right)$, with $z_{0}$ the altitude where all systems are located, is obtained from the meteorological station co-located with the $M W R$. Although the equation 1 is applied only in dry process, due to conditions of low $R H$ prevailing in Granada through the year (Bedoya-Velásquez et al., 2019), it was used in all cases.

The $\theta(z)$ profile is analyzed in order to label the situation as stable or unstable. Such analysis is made by comparing the surface potential temperature $\theta\left(z_{0}\right)$ with all points in $\theta(z)$ profile below $5 \mathrm{~km}$. If all points are larger than $\theta\left(z_{0}\right)$ the situation is considered stable and TGM is applied, otherwise the situation is assumed as unstable and $P M$ is used instead (Fig. 1).

The $P M$ only can be applied under unstable situations (i.e. for detecting $C B L$ ), as shown in Fig. 2. This method determines $C B L H_{M W R}$ as the altitude where an air parcel with an ambient temperature $T$ can rise adiabatically from the ground by convection (Holzworth, 1964; Coen et al., 2014). This is equivalent to affirm that $C B L H_{M W R}$ is the altitude (z) where the potential temperature $\theta(z)$ is equal to surface potential temperature $\theta\left(z_{0}\right)$. Due to the variable vertical resolution of MWR, in some situations the $C B L H_{M W R}$ is obtained from linear interpolation.

TGM (Stull, 1988; Coen et al., 2014) detects the $P B L H_{M W R}$ under stable situations based on two definitions; The first one relies on surface-based temperature inversion $(S B I)$, and identifies the first height where $T$ decrease as a function of altitude (Fig. 3). The second one, based on the top of Stable Boundary Layer (TSBL), determines the $P B L H$ as the first height where $\theta$ does not change with $\mathrm{z}$, in other words, $d \theta / d z=$ 0 (Fig. 3). In principle, this method detects the height where the $S B I$ is situated in the $T$ profile. Then, from this height is identified the TSBL $\left(S B L H_{M W R}\right)$ in the $\theta(z)$. Otherwise, $S B L H_{M W R}$ is labelled as "not identified".

\subsection{Ceilometer gradient method}

As mentioned before, ceilometers detect the $P B L H$ using aerosol as tracer and aerosol backscatter as observed quantity, similarly to lidar systems (Steyn et al., 1999), applying the same algorithms to both instruments. However, the relatively low $S N R$ of ceilometers represents a challenge for accurate PBLH detection, mainly under complex scenarios, such as in the presence of several decoupled aerosol layers (Steyn et al., 1999). Some widely applied algorithms based on significant changes in the ceilometer signal profile are: Threshold Method [TM] (Boers and Eloranta, 1986), Variance Method [VM] (Haij et al., 2007), Ideal Fit [IF] (Steyn et al., 1999; Eresmaa et al., 2006; Avolio et al., 2017), Wavelet Covariance Transform [WCT] (Haij et al., 2007; Münkel et al., 2007; Uzan et al., 2016; Caicedo et al., 2017), Gradient Method [GM] (Tsaknakis et al., 2011; Haman et al., 2012; Helmis et al., 2012; Stachlewskaet al., 2012; Wagner and Schäfer, 2017) and Bl-View (combination between GM and IF) (Vaisala Oyj, 2011; Caicedo et al., 2017). In addition, there is some algorithms, which are composed by several detection methods, like: Structure of the Atmosphere [STRAT] (Morille et al., 2007) and PathfinderT URB (Poltera, 2017). Nonetheless, it is 
necessary to note that all methods have advantages and disadvantages. A more detailed comparison among the most applied methods can be found in Eresmaa et al. (2012) and Haeffelin et al. (2012).

In this work the $G M$ is used to $P B L H_{\text {ceilometer }}$ detection, because it does not need a complex selection of specific parameters like as $T M, I F$ or $W C T$, allowing the analysis of the 4-year time series in an automated way and being able to provide results with good reliability (Tsaknakis et al., 2011), although it has limitations mainly in complex atmospheric conditions (rainy and/or cloudy days) (Paul et al., 2010). GM consists in detecting the minimum of gradient in the range corrected signal profile $(\operatorname{RCS}(z)$, defined as the ceilometer signal corrected by background radiation and the square of distance). Due to a typical reduction of aerosol concentration in the free troposphere $(F T)$ compared to $P B L$, this transition region (corresponding to $P B L H_{\text {ceilometer }}$ ) is characterized by an abrupt reduction in $R C S(z)$ signal.

$$
P B L H_{\text {ceilometer }}=\min \left(\frac{d \overline{R C S}(z)}{d z}\right)
$$

where the $\overline{R C S(z)}$ is the 10-min average of the $\operatorname{RCS}(z)$ profiles, in order to reduce the effect of noise in the analyzed profiles. $G M$ has some limitations in complex atmospheric conditions. Such situations generate ambiguities in the results, where $P B L H_{\text {ceilometer }}$ might be over or underestimated (Caicedo et al., 2017). Rainy, foggy, and cloudy days typically saturated the RCS above $200 \times 10^{-5} \mathrm{sr}^{-1} \mathrm{~km}^{-1}$. Therefore, in the longterm study a threshold analysis is performed over the whole ceilometer data series, cases with attenuated backscatter coefficients above the mentioned threshold are flagged and their profiles removed, as performed by Kamp et al. (2010) and Caicedo et al. (2017). Since Saharan dust outbreaks are frequent in Granada, Bravo-Aranda et al., 2017 used depolarization technique to distinguish between different layers (local aerosol and Saharan dust) and to detect he $P B L H$. However, the ceilometer used in this work does not have this capability and, therefore, cases of decoupled Saharan dust layers were manually identified using an ancillary multi-wavelength lidar (MULHACEN) and, then, these cases were manually removed. Saharan dust outbreak cases are more frequent in summer, representing around 30\% of removed cases. Table 1 shows the percentage of removed profiles due to our quality control.

\subsection{Variables for long term analysis}

The statistical analysis of the $C B L H$ includes the seasonal mean and the variables described below:

- Maximum of $\boldsymbol{C B L H _ { M W R }}\left(\boldsymbol{C B L H _ { M W R } ^ { M a x }}\right)$ : The $C B L H_{M W R}^{M a x}$ represents the maximum daily value of $C B L H_{M W R}$.

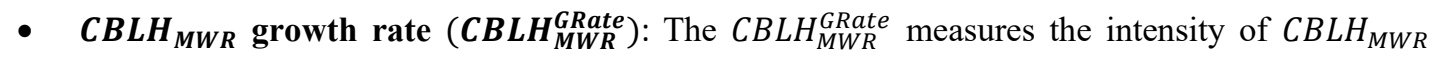
growth. It is obtained from a slope of a linear fit of the first $C B L H$ detected after sunrise and the last point to reach $90 \%$ of daily $C B L H_{M W R}$ maximum value, like as performed by Baars et al. (2008), Korhonen et al. (2014), Schween et al. (2014) and Pal et al. (2015).

- $\quad \boldsymbol{C B} \boldsymbol{L} \boldsymbol{H}_{M W R}$ growth speed $\left(\boldsymbol{C B} \boldsymbol{L} \boldsymbol{H}_{M W R}^{G S p e e d}\right)$ : The $C B L H_{M W R}^{G S p e e d}$ represents the variation of $C B L H_{M W R}$ during a determined time interval: 


$$
C B L H_{M W R}^{G S p e e d}=C B L H_{M W R}\left(t_{n}\right)-C B L H_{M W R}\left(t_{n-1}\right)
$$

In this work, the $C B L H_{M W R}^{G S p e e d}$ is calculated from the hourly mean difference of $C B L H_{M W R}$ in two consecutive hours.

- $\quad C B L H_{M W R}$ growth duration $\left(C B L H_{M W R}^{G D u r}\right)$ : The $C B L H_{M W R}^{G D u r}$ represents the number of hours after sunrise where $C B L H_{M W R}^{G S p e e d}$ is larger than zero. In other words, it represents the interval time between the time of beginning of $C B L H_{M W R}$ growth and when the $C B L H_{M W R}^{M a x}$ is reached (Pal et al., 2015).

\section{$4 P B L$ long term analysis}

\subsection{Study of the $P B L$ based on $M W R$}

$M W R$ operates continuously, even under rainy and cloudy scenarios, with low interruption periods (which are associated with maintenance, calibration and power outage). With the exception of summer 2015, the maintenance and failures did not affect more than $27 \%$ of data and thus, the MWR measurement covers more than $70 \%$ of the period 2012-2016. Table 2 shows the distribution of data recovery rate per season and per year, and the percentage of measurement days.

The long-term study performed with $M W R$ data at Granada is compared with same kind of study performed at other locations, such as eastern part of the Highveld region (a large plateau in South Africa composed by rural area with agriculture, mining and industrial activities) (Korhonen et al., 2017), Palaiseau (on the Saclay plateau in a suburban environment surrounded by villages, agricultural fields and some roads) (Pal et al., 2015), Jülich (situated in a flat region and surrounded by some hills at east and west, and it is district of the fourth most populated city in Germany) (Schween et al., 2014), and Leipzig (a very populous city situated in a rather flat terrain with some forest parks within its limits and surrounded by a relatively unforested region) (Baars et al., 2008). Table 3 presents some characteristics of each campaign, e.g., localization, instrument and algorithm.

Figure 4 we show the average daily evolution of $P B L H_{M W R}$ since 2012 until 2016. The $P B L H_{M W R}$ has low values in winter, maximum values in summer, spring and autumn with intermediate values which is the expected pattern being in agreement with the results showed by Pal et al. (2015) Palaiseau and Korhonenet al. (2014) at Highveld. However, the difference in site latitudes, ground cover and city size result in distinct average values. For example, the average maximum PBLH value in winter is larger in Highveld (1480 m) than in Granada and Palaiseau (1000 m). In summer, Granada and Palaiseau have practically the same average maximum values (around $2000 \pm 700 \mathrm{~m}$ in Granada and $1900 \pm 400 \mathrm{~m}$ in Palaiseau).

Figure 5 shows daily $P B L H_{M W R}$ variation for each season for the whole period 2012-2016. As can be seen, in all seasons $P B L H_{M W R}$ shows a very clear diurnal cycle with low values in night and high ones in the early afternoon. Also, in all seasons, $P B L H_{M W R}$ has a similar behavior with low variability during the night 
stable period, except in the summer, where the whiskers show larger range of values. Similar daily behavior was observed by Pal et al. (2015) in Palaiseau, where, outside of summer, the average PBLH variation in stable situations is around $200 \mathrm{~m}$. During convective period (day time) the differences among the seasons are more evident. This is in good agreement with other studies (e.g. Stull, 1988; van der Kamp and McKendry, 2010; Seidel et al., 2012; Pal et al., 2015; Chen et al., 2016), showing that the average value of $P B L H$ is low in winter and reaches its apex in summer. The $P B L H_{M W R}$ in spring is similar to autumn, but with slightly higher average and larger spread of values, as can be seen in the whisker boxes.

The $C B L H_{M W R}^{G S p e e d}$ offers an interesting insight on the $C B L$ behavior. Figure 6 presents average value of this variable for all seasons in the period 2012-2016, from the first point where $C B L$ begins to grow until the moment where it does not increase $\left(C B L H_{M W R}^{G S p e e d}=0\right)$. All seasons have the same pattern, a continuous growth of $C B L H_{M W R}^{G S p e e d}$ in the first hours after sunrise due to increase of convective process. Then, around $10 \mathrm{UTC}$, the growth rate of $C B L H_{M W R}^{G S p e e d}$ begins to increase more slowly (in summer around 11 UTC) until the moment where the $C B L H_{M W R}^{G S p e e d}$ reach a stationary value (winter: $2.8 \mathrm{~m} / \mathrm{min}$, spring: $3.6 \mathrm{~m} / \mathrm{min}$, summer: $4.1 \mathrm{~m} / \mathrm{min}$ and autumn: $3.1 \mathrm{~m} / \mathrm{min}$ ). After some moments, $C B L H_{M W R}^{G S \text { Speed }}$ begins to decrease until zero, it is the moment where the $C B L$ is fully-developed and its height practically does not vary with the time.

Maximum values of $C B L H_{M W R}^{G S p e e d}$ occur in summer when the diurnal cycle is wider (Fig. 6). This behavior is due to the high incidence of solar radiation on summer which favors the surface heating, generating stronger convective processes, as well as, higher period of variations in $C B L H_{M W R}$. Oppositely, winter with less solar radiation (low incident angle and few hours of Sun) is characterized by smaller absolute values of $C B L H_{M W R}^{G S p e e d}$ and lower time of alterations in $C B L H_{M W R}$. Spring and autumn present similar intermediate behaviors, with spring having a higher time of $C B L H_{M W R}$ growth.

Figure 7 shows the $C B L H_{M W R}^{M a x}$ histograms for the four seasons, including the skewness $\left(S_{k}\right)$, the normalized kurtosis $\left(K_{t}\right)$ and the average $\left(A_{v}\right)$ values. Winter and autumn histograms of $C B L H_{M W R}^{M a x}$ have an asymmetric shape $\left(S_{k}^{\text {winter }}=0.8\right.$ and $\left.S_{k}^{\text {autumn }}=0.6\right)$ biased toward small values, with $A_{v}$ of $1000 \pm 350$ and $1300 \pm 600$ $\mathrm{m}$, respectively. However, winter histogram present a higher $K_{t}$ value $\left(K_{t}^{\text {winter }}=0.2\right)$ with respect to autumn which presents a flatter distribution $\left(K_{t}^{\text {autumn }}=-0.5\right)$. Spring has an almost symmetric and flat distribution $\left(S_{k}^{\text {spring }}=0.1\right.$ and $\left.K_{t}^{\text {spring }}=-0.6\right)$ with average value of $1600 \pm 500 \mathrm{~m}$. Finally, summer has a flattest distribution $\left(K_{t}^{\text {summer }}=-0.7\right)$ with low asymmetry $\left(S_{k}^{\text {summer }}=0.3\right)$ and high number of cases localized in higher bins and an average value of $1900 \pm 700 \mathrm{~m}$. We found similar seasonal pattern as those determined in other cities like Leipzig (Baars et al., 2008), Jülich (Schween et al., 2014) and Palaiseau (Pal et al., 2015). Nevertheless, the different cities present differences in the average and the range of the variables used in $P B L$ description, thus larger values are obtained at Granada while the lowest ones correspond to Jülich.

The $C B L H_{M W R}^{G R a t e}$ is directly related with $C B L H_{M W R}^{G S p e e d}$ and, consequently in the same way that $C B L H_{M W R}^{G S P e e d}$ (Fig. 6), $C B L H_{M W R}^{G R a t e}$ presents a large seasonal variability (Fig. 8). The colder seasons have the lower average values as well as peaked distributions (higher values of $K_{t}$ - in winter $K_{t}=16.2$ ) with cases concentrated in 
left side of distribution, in other words, small values and vice versa in warmer season. Such behavior was expected due to the values of $C B L H_{M W R}^{G S p e e d}$ observed in Figure 6 (lower in colder seasons and higher in warmer one), which implies directly in the seasonality observed in Figure 8. Similar seasonal pattern in CBLH GWR Gate $_{M}$ was observed in Jülich (Schween et al., 2014) and Palaiseau (Pal et al., 2015), however $C B L H_{M W R}^{G R a t e}$ at Granada presents greater variability among seasons. Thus, while the difference between average values registered in summer and winter are around 80 and $100 \mathrm{~m} / \mathrm{h}$ in Jülich and Palaiseau, respectively, the difference in Granada was $180 \mathrm{~m} / \mathrm{h}$. This is associated to the large differences in meteorological conditions between the winter and summer in Granada, as reflected for example in the analysis of the temperature range and explained in Section 4.2.

The $C B L H_{M W R}^{G D u r}$ at Granada presents a clear seasonal pattern (Fig. 9). The average value in summer (6.2 \pm $2.0 \mathrm{~h})$ is larger than the average value in winter $(5.4 \pm 1.6 \mathrm{~h})$. This is consequence of earlier sunrise and later sunset in summer, enabling $C B L$ grows during larger time. In winter and autumn, the $C B L H_{M W R}^{G D u r}$ frequency distributions are more centered on low values, whereas in summer and spring they present a large spread with negative skewness $\left(S_{k}^{\text {spring }}=-0.1, K_{t}^{\text {spring }}=-0.6, S_{k}^{\text {summer }}=-0.2\right.$ and $\left.K_{t}^{\text {summer }}=-0.8\right)$. Granada, Jülich and Palaiseau present similar seasonal patterns of $C B L H^{G D u r}$, being the difference between summer and winter around $0.9 \mathrm{~h}$ at Granada and $3.6 \mathrm{~h}$ at Paris, with Jülich in between. Such differences evidence the influence of latitude in the variables describing $P B L$ structure used in this statistical analysis.

Table 4 summarized the comparison among the values of $C B L H^{\text {Max }}, C B L H^{G R a t e}$ and $C B L H^{G D u r}$ obtained at Leipizig (Baars et al. 2008), Jülich (Schween et al. 2014), Palaiseau (Pal et al., 2015) and Granada. It is evident the seasonal pattern of the different variables at all the stations. $C B L H^{\operatorname{Max}}$ presents similar values and ranges at Granada and Palaiseau that are larger than those determined at the other stations with high latitude. Concerning $C B L H^{G R a t e}$, it is clear that Granada presents larger values associated to the larger solar irradiance all around the year. Furthermore, the values of Granada also present a larger seasonal range than the other sites, thus suggesting really dry conditions in summer that favor strong convective processes shortly after sunrise. As mentioned previously, Granada presents values of $C B L H^{M a x}$ higher than Jülich and similar to Palaiseau. This characteristic combined with the larger values of $C B L H^{G R a t e}$ results in the $C B L H^{G D u r}$ smaller than that observed in the others two sites.

\subsection{Links between $P B L, B C$ surface concentrations and meteorological variables}

Figure 10 shows the average daily pattern for $T_{\text {air }}, R H$ and net radiation $\left(R_{n}\right)$ together with the $P B L H_{M W R}$ for all seasons in the period 2012-2016. We have estimated $R_{n}$ from the global solar irradiance using the seasonal model described in Alados et al. (2003) (Fig. 10). As expected, due to the different levels of incidence of solar radiation, the higher values of $R_{n}$ are registered in summer and they continuously decrease until the winter. In all seasons, the higher values are observed in central region of day around 13:00 UTC, close to moment when $C B L H_{M W R}$ is fully developed. There is a clear link between the start of positive $R_{n}$ and the starting time of $C B L H_{M W R}$ growth (Fig. 6), as well as, with $C B L H_{M W R}^{G R a t e}$ (Fig. 8) and $C B L H_{M W R}^{G D u r}$ (Fig. 9) in all seasons. The offset between $P B L H_{M W R}$ and $R_{n}$ may be explained based on the 
1 thermal and mechanical inertia of the atmosphere which requires some time to dissipate the convection

2 cells. The low variation of the $S B L H_{M W R}$ average is also associated with negative and practically constant

3 values of $R_{n}$.

4 During summer and spring, the $T_{\text {air }}$ rising (triangles) occurs at approximately 06:00 UTC whereas this 5 increase is approximately at 07:30 UTC in winter and autumn. This delay between spring/summer and 6 autumn/winter is due to the changes in the insolation period (dotted yellow and red lines represent the 7 average hours of sunrise and sunset, respectively - Fig.10), $R_{n}$ values, the influence of heat conductive

8 fluxes from/to the ground and the dry land with reduced vegetation typical of summer conditions.

9 Studies performed in other regions such as Palaiseau and Highveld (Pal et al., 2015; Kornohen et al., 2014)

10 reveal similar seasonal patterns for the $T_{\text {air }}$, although both the average air temperature and its interseasonal 11 range are different from site to site. For example, the average difference between maximum of $T_{\text {air }}$ in summer and winter is $20 \mathrm{~K}$ in Palaiseau, while in Highveld and Granada are $7 \mathrm{~K}$ and $26 \mathrm{~K}$, respectively. Such differences occur mainly due to latitude of each region, which influence the $R_{n}$ and consequently the $T_{\text {air }}$. This justifies the small difference of $C B L H^{\text {Max }}$ observed between summer and winter (around $500 \mathrm{~m}$ ) in Highveld, when compared to Palaiseau and Granada, where this variability is approximately 900 and $1000 \mathrm{~m}$, respectively.

The surface thermal amplitude (STA - the difference between the average minimum value of $T_{\text {air }}\left[\overline{T_{a i r}^{m i n}}\right]$ and average maximum value of the same variable $\left[\overline{T_{a l r}^{\max }}\right]$ ) at Granada is $9,12,9$, and $8 \mathrm{~K}$ for spring, summer, autumn, and winter, respectively. This seasonal change of STA justifies the pattern of $C B L H^{G R a t e}$ exhibited in Table 4. As it can be seen, the warmest and coldest seasons have the largest and lowest STA, respectively. The $S T A$ and $C B L H^{G R a t e}$ are directly related and such behavior is based on the intensification of convective process caused by the increase of $T_{\text {air }}$, which is directly related with $R_{n}$ and the latitude of each region, as aforementioned. A similar correlation occurs in Highveld, where low values of STA are observed ( $S T A_{\text {summer }}<9 \mathrm{~K}$ ) and consequently small values of $C B L H^{G R a t e}$ (median value of approximately $0.2 \mathrm{~km} / \mathrm{h}$ ) as compared to Granada.

The $R H$ at Granada presents its maximum in winter and its minimum summer (Fig. 10). At all seasons, the averages daily values of $R H$ are anti-correlated with $R_{n}, T_{\text {air }}$ and $P B L H_{M W R}$. Similar results also were observed by Pal et al. (2015), although values of $R H$ in Palaiseau are higher than the values in Granada for all seasons, due to higher evapotranspiration and Atlantic air masses influence at Palaiseau. However, our analysis does not allow us to establish a direct relationship between the level of interference of $R H$ in the behavior of $P B L$.

Concentration of the pollutants at any given location is governed, among other factors, by boundary layer dynamics and wind strength. The $P B L H$ and $v$ represent the vertical and horizontal diffusion capabilities of pollutants, respectively. So, the combination of these two variables can play a major role in the dispersion of the pollutants. In this sense, the so-called ventilation coefficient $(V C)$ is generally used to measure the capability of atmospheric vertical and horizontal dispersion of air pollutant (Nair et al., 2007; Gaur et al., 
shows the seasonal diurnal variability of $B C$ concentration and $V C$ for 2012-2016. The highest values of $B C$ were found in winter and the lowest values in summer. The highest $B C$ concentration in winter is associated with lower $P B L H$ and increased anthropogenic emissions from domestic heating in season (Lyamani et a., 2001; Titos et al., 2017). In all seasons, BC shows a very clear daily pattern with two peaks coinciding with traffic rush hours and two minima at night and afternoon hours. Similar seasonal and diurnal $B C$ cycles were observed in the same study area by Lyamani et al. (2011) and Patron et al., (2016), which were attributed to the variation in both $P B L$ dynamics and anthropogenic activities. The first daily $B C$ maximum reaches values up to $7,5 \mu \mathrm{g} \mathrm{m}^{-3}$ in winter and $4 \mu \mathrm{g} \mathrm{m}^{-3}$ in summer, while the second $B C$ maximum presents values of 5 and $2 \mu \mathrm{g} \mathrm{m}^{-3}$, respectively. The minimum $B C$ concentration observed at night and early morning in all season is associated with a drastic reduction in anthropogenic activities (traffic). However, the lower concentrations of $B C$ observed around 15:00 UTC in all seasons are mainly linked to the increase in $V C$. Nevertheless, the $P B L$ dynamic alone cannot explain the daily and seasonal behaviors of $B C$ and other factors such as change in traffic emissions must be taken into account in order to better understand $B C$ behavior. This fact is clearly illustrated in Figure 12, which shows $B C$ concentration versus $V C$. As can be seen in this figure there is no clear relation between $B C$ and $V C$. However, in all season and for $B C>5 \mu \mathrm{g} \mathrm{m}^{-3}$, the increase in $\mathrm{BC}$ concentration is associated to the decrease in $V C$ and $P B L H_{M W R}$ (Fig. 5). This was also observed by other authors in other urban areas (e.g. Petäjäet al., 2016 and Ding et al., 2016). Thus, the reduction in atmospheric ventilation leads to increased $B C$ concentration that leads to air quality deterioration. Using model simulations and various field observations, Ding et al., (2016) demonstrated that $B C$ induces heating in the $P B L$ which results in decreased surface heat flux and substantially depresses the development of $P B L$ and consequently enhances surface $B C$ concentration. Therefore, reduction of $B C$ emissions is an efficient way to improve air quality.

\subsection{Study of the $P B L$ based on ceilometer: Searching the Residual Layer}

The ceilometer located at IISTA-CEAMA measured without failures during $96 \%$ of the days from January 2013 until December 2016. However, the number of successful PBLH retrievals with the ceilometer (Table 5) are lower than those retrieved with the $M W R$ due to influence of atmospheric conditions in aerosol backscatter profiles (Eresma et al., 2006), preventing $P B L H_{\text {Ceilometer }}$ detection under complex situations (rainy, clouds, Saharan dust layers). These cases were flagged and removed as explained in section 3.1.2. The lowest retrieval rate is registered in autumn, due to the rain and still the occurrence of Saharan mineral dust outbreaks.

Figure 13 shows the average daily $P B L H_{\text {Ceilometer }}$ variation from 2013 until 2016. As mentioned before, the ceilometer detects the height of Residual Layer $\left(R L H_{\text {Ceilometer }}\right)$ between sunset and sunrise. Similarly to $S B L H_{M W R}, R L H_{\text {Ceilometer }}$ is influenced by the low values of $R_{n}$ and presents low variability (often remaining around $1000 \mathrm{~m} \mathrm{agl}$ ), which is a common characteristic for all seasons. $G M$ allows the $C B L H_{\text {Ceilometer }}$ detection when the $C B L$ is fully developed, reaching the previous-day $R L$ height. Thus, the variation observed in this period is large, mainly in summer, when $S T A$ and $R_{n}$ reaches the largest values. In addition, the values of $C B L H_{\text {Ceilometer }}$ between 13 and $16 \mathrm{UTC}$ are close of the values of $C B L H_{M W R}$ in 
1 this same period (Fig. 4), as expected. Tang et al. (2016) observed that windy days can influence the 2 ceilometers detection, causing an overestimation of $P B L H$ detection. These events can have influenced the

$3 \quad C B L H$ estimation from ceilometer data resulting in the average values higher that one obtained from MWR data.

5 The average values of $P B L H_{\text {Ceilometer }}$ and $P B L H_{M W R}$ are shown in Figure 14. Only days with these two instruments simultaneously operating are considered. This combination allow for observing the seasonal behavior of the complex $P B L$ structure based on the complementary information provided by $R L H_{\text {Ceilometer }}, C B L H_{\text {Ceilometer }}, C B L H_{M W R}$ and $S B L H_{M W R}$, since the presence of these variables is related with the $P B L$ daily cycle presented in previous sections. The same daily pattern described in section 4.1 is observed, as well as the seasonality demonstrated in Figures 4 and 13 for $P B L H_{M W R}$ and $P B L H_{\text {Ceilometer }}$, respectively. In addition, from the Figure 14 is possible to observe the average $R L$ depth $\left(\triangle P B L H=P B L H_{\text {Ceilometer }}-P B L H_{M W R}\right)$ for all seasons from 2013 until 2016. During period of $S B L$, the $R L$ depth is between 700 and $800 \mathrm{~m}$ for all seasons, however in the course of $C B L$ growth, $R L$ depth decreases until the moment where it is broken by the $C B L$ (around 10 UTC).

\section{Summary and conclusions}

This paper has shown a study about $P B L H$ obtained from the combination of ceilometer and $M W R$ measurements. $C B L H_{\text {Ceilometer }}$ was obtained by the gradient method, which detects the top of aerosol layer, which corresponds to the top of the convective boundary layer if $P B L$ is fully developed and to the top of the residual layer otherwise and, $P B L H_{M W R}$ was obtained by means of an algorithm that combines the parcel method and temperature gradient method, allowing to differentiate between stable boundary layer and convective boundary layer cases.

The long-term analyses allowed for providing a statistical study of the $P B L H$ at a middle-latitude urban site in Granada, which contributes to increase the general knowledge on the $P B L$ pattern in Europe at different latitudes reported in previous studies, such as Palaiseau, Highveld, and Jülich. We concluded the following features for the $P B L$ of Granada: daily maximum convective boundary layer height $(1600 \pm 500 \mathrm{~m}$ in Spring, $2000 \pm 700 \mathrm{~m}$ in Summer, $1300 \pm 600 \mathrm{~m}$ in Autumn, $1000 \pm 350 \mathrm{~m}$ in Winter), convective boundary layer height growth rate $(300 \pm 160 \mathrm{~m} / \mathrm{h}$ in Spring, $400 \pm 300 \mathrm{~m} / \mathrm{h}$ in Summer, $230 \pm 140 \mathrm{~m} / \mathrm{h}$ in Autumn, $220 \pm 140 \mathrm{~m} / \mathrm{h}$ in Winter) and convective boundary layer height growth duration $(6.1 \pm 1.8 \mathrm{~h}$ in Spring, 6.2 $\pm 1.9 \mathrm{~h}$ in Summer, $5.4 \pm 1.7 \mathrm{~h}$ in Autumn, $5.3 \pm 1.5 \mathrm{~h}$ in Winter), which demonstrates the PBL seasonality in this region and as the surface meteorological variables, involved in the thermodynamic processes, correlated with the $P B L H$, mainly net radiation and surface thermal amplitude.

Since the $P B L$ dynamics is an important meteorological factor that affects the vertical diffusion of atmospheric pollutants influencing the air quality, we have also analyzed back carbon concentration as a tracer of the traffic emissions to characterize the air pollution at our urban site, along with the conventional meteorological variables. We have used the ventilation coefficient to take into account the capability of the atmosphere for the pollutant diffusion. We concluded that the lowest concentrations of black carbon found in all seasons during central hours of the day coincide with the highest values of $V C\left(4000 \mathrm{~m}^{2} \mathrm{~s}^{-1}\right.$ in summer 
and $1600 \mathrm{~m}^{2} \mathrm{~s}^{-1}$ in winter). However, due to weak $v$ and low values for $P B L$, a low vertical (convective) and horizontal mixing of aerosol particles are generated at surface level, with the highest values of black carbon in winter coinciding to the rush traffic hours (values up to $7-5 \mu \mathrm{g} \mathrm{m}^{-3}$ in the morning and $5 \mu \mathrm{g} \mathrm{m}^{-3}$ in the evening). This combination of variables allows for concluding the variation of black carbon concentration during the different seasons is directly related with the seasonal behavior of the $P B L H$ and, consequently, the ventilation coefficient.

We also concluded that only the residual layer height is not affected by the seasonality of meteorological variables, being its value practically constant (around $1000 \mathrm{~m} \mathrm{agl}$ ) through the year. In this regard, we have shown how the combination of the $P B L H_{M W R}$ and $P B L H_{\text {Ceilometer }}$ during stable conditions, and until around 10 UTC in convective situations, allowed the retrieval of the residual layer depth, opening the door to further investigations about the air quality due to the potential entrainment of the residual layer aerosol load in the next convective boundary layer .

This study has demonstrated the feasibility of long-term $P B L H$ analysis using ceilometer and $M W R$, enabling the characterization of this variable and a better comprehension about its behavior, complex structure and how seasonality, geographical differences and surface variables can influence it, along with the relevance of the role of PBL dynamics in the ability to diffuse atmospheric pollutants. In the future we will intend to extend this study to other regions and synergistically aggregate other remote sensing systems.

\section{Acknowledgements}

This work was supported by the Spanish Ministry of Economy and Competitiveness through projects CGL2015-73250-JIN, CGL2016-81092-R, CGL2017-83538-C3-1-R and CGL2017-90884-REDT, and by the University of Granada through "Plan Propio. Programa 9 Convocatoria 2013. The financial support for EARLINET in the ACTRIS Research Infrastructure Project by the European Union's Horizon 2020 research and innovation program through project ACTRIS-2 (grant agreement No 654109). The authors thankfully acknowledge the FEDER program for the instrumentation used in this work and the University of Granada that supported this study through the Excellence Units Program. COST Action TOPROF (ES1303), supported by COST (European Cooperation in Science and Technology), is also acknowledged.

\section{References}

Alados, I., Foyo-Moreno, I., Olmo, F. J., Alados-Arboledas, L, 2003. Relationship between net radiation and solar radiation for semi-arid shrub-land. Agr. Forest Meteorol., 116, 221-227.

Alados-Arboledas, L., Olmo, F. J., Alados, I., Perez, M., 1999. Parametric models to estimate photosynthetically active radiation in Spain. Agric. For. Meteorol., 101, pp. 187-201

Alados-Arboledas, L., Müller, D., Guerrero-Rascado, J., Navas-Guzmán, F., Pérez-Ramírez, D., and Olmo, F., 2011.Optical and microphysical properties of fresh biomass burning aerosol retrieved by Raman lidar, and star-and sun-photometry, Geophys. Res.Lett. 38, L01807, doi: 10.1029/2010GL045999. 
Avolio, E., Federico, S., Miglietta, M. M., Feudo, T. Lo, Calidonna, C. R., Sempreviva, A. M.,2017. Sensitivity analysis of WRF model PBL schemes in simulating boundary- layer variables in southern Italy : An experimental campaign. Atmos. Res., 192, 58-71.

Baars, H., Ansmann, a., Engelmann, R., Althausen, D., 2008. Continuous monitoring of the boundarylayer top with lidar. Atmos. Chem. Phys., 8(3), 10749-10790. http://doi.org/10.5194/acpd-8-10749-2008.

Bedoya-Velásquez, A.E., Navas-Guzmán, F., de Arruda Moreira, G., Román, R., Cazorla, A., OrtizAmezcua, P., Benavent-Oltra, J.A., Alados-Arboledas, L., Olmo-Reyes, F.J., Foyo-Moreno, I., MontillaRosero, E., Hoyos, C.D., Guerrero-Rascado, J.L., 2019. Seasonal analysis of the atmosphere during five years by using microwave radiometry over a mid-latitude site, Atmos. Res., 218, pp. 78-89, https://doi.org/10.1016/j.atmosres.2018.11.014.

Bianco, L., Cimini, D., Marzano, F. S.,Ware, R., 2005. Combiningmicrowave radiometer and wind profiler radar measurements for high-resolution atmospheric humidity profiling. J. Atmos. Ocean. Tech., 22, 949965.

Boers, R., Eloranta, E. W., 1986. Lidar Measurements of the Atmospheric Entrainment Zone and the Potential Temperature Jump Across the Top of the Mixed Layer. Bound-Lay. Meteorol., 34, 357-37.

Bravo-aranda, J. A., Moreira, G. de A., Navas-Guzmán, F., Granados-Muñoz, M. J., Guerrero-Rascado, J. L., Pozo-Vázquez, D., Arbizu-Barrena, C., 2017. A new methodology for PBL height estimations based on lidar depolarization measurements : analysis and comparison against MWR and WRF model-based results. Atmos. Chem. Phys., 17, 6839-6851. https://doi.org/10.5194/acp-17-6839-201.

Caicedo, V., Rappenglück, B., Lefer, B., Morris, G., Toledo, D., Delgado, R., 2017. Comparison of aerosol lidar retrieval methods for boundary layer height detection using ceilometer aerosol backscatter data. Atmos. Chem. Phys., 10, 1609-1622. https://doi.org/10.5194/amt-10-1609-2017.

Caumont, O., Cimini, D., Löhnert, U., Alados-Arboledas, L., Bleisch, R., Buffa, F., Ferrario, M.E., Haefele, A., Huet, T., Madonna, F., Pace, G., 2016. Assimilation of humidity and temperature observations retrieved from ground-based microwave radiometers into a convective-scale NWP model. Q. J. Roy. Meteor. Soc., 142 (700), 2692-2704.

Cazorla, A., Casquero-Vera, J. A., Román, R., Guerrero-Rascado, J. L., Toledano, C., Cachorro, V. E., Orza, J. A. G., Cancillo, M. L., Serrano, A., Titos, G., Pandolfi, M., Alastuey, A., Hanrieder, N., AladosArboledas, L., 2017. Near-real-time processing of a ceilometer network assisted with sun-photometer data: monitoring a dust outbreak over the Iberian Peninsula, Atmos. Chem. Phys., 17, 11861-11876, https://doi.org/10.5194/acp-17-11861-2017.

Cimini, D., Angelis, F. de, Dupont, J.-C., Pal, S., Haeffelin, M., 2013. Mixing layer height retrievals by multichannel microwave radiometer observations. Atmos. Meas. Tech., 6, 2941-2951. http://doi.org/10.5194/amt-6-2941-2013. 
1 Cimini, D., Nelson, M., Güldner, J., Ware, R., 2015.Forecast indices from ground-based microwave

2 radiometer for operational meteorology. Atmos. Meas. Tech.,8,315 - 333.

3 Chen, F., Kusaka, H., Bornstein, R., Ching, J., Grimmon, C. S. B., Grossman-Clarke, S., Loridan, T., 4 Manning, K. W., Martilli, A., Miao, S., Sailor, D., Salamanca, F. P., Taha, H., Tewari, M., Wang, X., 5 Wyszogrodzki, A. A., Zhang, C., 2011. The integrated WRF/urban modelling system: development, 6 evaluation, and applications to urban environmental problems. Int. J.Climatol., 31, 2, 273-288.

7 Chen, X., Skerlak, B., Rotach, M. W., Añel, J. A., Su, Z., Ma, Y., Li, M., 2016. Reasons for the extremely 8 high-ranging planetary boundary layer over the western tibetan plateau in winter. J. Atmos. Sci., 73, 2021 9 - 2038DOI: 10.1175/JAS-D-15-0148.1.

Coen, M. C., Praz, C., Haefele, A., Ruffieux, D., Kaufmann, P.,Calpini, B., 2014. Determination and climatology of the planetary boundary layer height above the Swiss plateau by in situ and remote sensing measurements as well as by the COSMO-2 model. Atmos. Chem. Phys., 14, 13205-13221. https://doi.org/10.5194/acp-14-13205-2014.

Córdoba-Jabonero, C., Sorribas, M., Guerrero-Rascado, J. L., Adame, J. A., Hernández, Y., Lyamani, H., Cachorro, V., Gil, M., Alados-Arboledas, L., Cuevas, E., de la Morena, B., 2011. Synergetic monitoring of Saharan dust plumes and potential impact on surface: A case study of dust transport from Canary Islands to Iberian Peninsula. Atmos. Chem. Phys., 11, 7, 3067-3091.

de Arruda Moreira, G. , Guerrero-Rascado, J. L., Bravo-Aranda, J. A., Benavent-Oltra, J. A., OrtizAmezcua, P., Róman, R., Bedoya-Velásquez, A. E., Landulfo, E., Alados-Arboledas, L. , 2018. Study of the planetary boundary layer by microwave radiometer, elastic lidar and Doppler lidar estimations in Southern Iberian Peninsula. Atmos.Res., 213, 185-195. de Arruda Moreira, G., Guerrero-Rascado, J. L., Benavent-Oltra, J. A., Ortiz-Amezcua, P., Román, R., E. Bedoya-Velásquez, A., Bravo-Aranda, J. A., Olmo Reyes, F. J., Landulfo, E., and Alados-Arboledas, L., 2019: Analyzing the turbulent planetary boundary layer by remote sensing systems: the Doppler wind lidar, aerosol elastic lidar and microwave radiometer, Atmos. Chem. Phys., 19, 1263-1280, https://doi.org/10.5194/acp-19-1263-2019.

del Águila, A., Sorribas, M., Lyamani, H., Titos, G., Olmo, F., Arruda-Moreira, G., Yela, M., AladosArboledas, L., 2018. Sources and physicochemical characteristics of submicron aerosols during three intensive campaigns in Granada (Spain), Atmos. Res., 213, 398-410, https://doi.org/10.1016/j.atmosres.2018.06.004.

Deardorff, J. W., Willis, G. E., Stockton, B. H., 1980. Laboratory studies of the entrainment zone of a convectively mixed layer. J. Fluid. Mech., 100, 41-64. of atmospheric boundary layer height using ceilometer backscatter data assisted by a boundary layer model. Q. J. Roy. Meteor. Soc., 138, 649-663. https://doi.org/10.1002/qj.964. 
1 Ding, A.J., Huang, X., Nie, W., Sun, J.N., Kerminen, V.M., Petäjä, T., Chi, X.G., 2016. Enhanced haze

2 pollution by black carbon in megacities in China. Geophys. Res. Lett. 43 (6), 2873-2879.

3 Eresmaa, N., Karppinen, A., Jofre, S. M., Räsänen, J. V., Talvitie, H., 2006. Mixing height determination 4 by ceilometer. Atmos. Chem. Phys., 6, 1485-1493, https://doi.org/10.5194/acp-6-1485-2006.

5 Eresmaa, N., Härkönen, J., Joffre, S. M., Schultz, D. M., Karppinen, A., Kukkonen, J.A., 2012. three-step 6 method for estimating the mixing height using ceilometer data from the Helsinki testbed. J. Appl. Meteorol.

$7 \quad$ Clim., 51, 2172-2187.

8 Foyo-Moreno, I., Alados, I., Antón, M., Fernández-Gálvez, J., Cazorla, A. and Alados-Arboledas, L, 2014.

9 Estimating aerosol characteristics from solar irradiance measurements at an urban location in southeastern

10 Spain. J. Geophys, Res-Atmos., 119 (4), 1845-1859.

11 Gaur, A., Tripathi, S.N., Kanawade, V.P., Tare, V., Shukla, S.P., 2014. Four-year measurements of trace gases (SO2, NOx, CO, andO3) at an urban location, Kanpur, in Northern India. J. Atmos. Chem. 71, 283301.

Granados-Muñoz, M. J., Navas-Guzmán, F., Bravo-Aranda, J. A., Guerrero-Rascado, J. L., Lyamani, H., Fernández-Gálvez, J., Alados-Arboledas, L., 2012. Automatic determination of the planetary boundary layer height using lidar: One-year analysis over southeastern Spain. J. Geophys. Res-Atmos., 117, D18208, https://doi.org/10.1029/2012JD017524.

Granados-Muñoz M.J, Navas-Guzmán, F., Bravo-Aranda, J. A., Guerrero-Rascado, J. L., Lyamani, H., Valenzuela, A., Titos, G., Fernández-Gálvez, J., Alados-Arboledas, L., 2015.Hygroscopic growth of atmospheric aerosol particles based on active remote sensing and radiosounding measurements: selected cases in southeastern Spain. Atmos. Meas. Tech., 8, 705-718.

Granados-Muñoz, M.J.,Bravo-Aranda, J.A.,Baumgardner, D.,Guerrero-Rascado, J.L.,Pérez-Ramírez, D.,Navas-Guzmán, F.,Veselovskii, I.,Lyamani, H.,Valenzuela, A.,Olmo, F.J.,Titos, G.,Andrey, J.,Chaikovsky, A.,Dubovik, O.,Gil-Ojeda, M.,Alados-Arboledas, L., 2016. A comparative study of aerosol microphysical properties retrieved from ground-based remote sensing and aircraft in situ measurements during a Saharan dust event. Atmos. Meas. Tech., 9, 3, 1113-1133.

Guerrero-Rascado, J.L., Ruiz, B., Alados-Arboledas, L., 2008a. Multi-spectral Lidar characterization of the vertical structure of Saharan dust aerosol over southern Spain. Atmos. Environ., 42, 11, 2668-268.

Guerrero-Rascado, J.L., Ruiz, B., Chourdakis, G., Georgoussis, G., Alados-Arboledas, L., 2008b.One year of water vapour Raman lidar measurements at the Andalusian Centre for Environmental Studies (CEAMA), Int. J. Remote Sens., 29, 5437-5453. Haeffelin, M., Angelini, F., Morille, Y., Martucci, G., Frey, S., Gobbi, G. P., Lolli, S., O’Dowd, C. D., Sauvage, L., Xueref- Rémy, L., Wastine, B., and Feist, D. G., 2012. Evaluation, of mixing- height retrievals from automatic profiling lidars and ceilometers in view of future integrated networks in Europe. Bound. 
1 Haij M, Wauben W, Klein Baltink H., 2007. Continuous mixing layer height determination using the LD-

240 ceilometer: a feasibility study. KNMI scientific report, Royal Netherlands Meteorological Institute.

3 Hennemuth.

4 Haman, C. L., Lefer, B., Morris, G. A., 2012. Seasonal variability in the diurnal evolution of the boundary

5 layer in a Near-Coastal: Urban environment. J. Atmos. Ocean. Tech., 29(5), 697-710.

6 https://doi.org/10.1175/JTECH-D-11-00114.1.

7 Hamilton, R.S., Mansfield, T.A., 1991. Airborne particulate elemental carbon-Its sources, transport and

8 contribution to dark smoke and soiling. Atmos. Environ., 25A, 715-723.

9 He, Q. S., Mao, J. T., Chen, J. Y., Hu, Y. Y., 2006. Observational and modeling studies of urban 10 atmospheric boundary-layer height and its evolution mechanisms. Atmos. Environ., 40(6), $1064-1077$. https://doi.org/10.1016/j.atmosenv.2005.11.016.

Helmis C. G., Sgouros, G., Tombrou, M., Schäfer, K., Münkel, C., Bossioli E., Dandou, A. A., 2012.Comparative study and evaluation of mixing-height estimation based on sodar-RASS, ceilometer data and numerical model simulations. Bound. Lay. Meteorol, 145:507-526.

Holzworth, C. G., 1964. Estimates of mean maximum mixing depths in the contiguous United States. Monthly Weather Review, 92, 235-242.

INE - Instituto Nacional de Estadística, 2018. Demography and population. Available at http://www.ine.es/dynt3/inebase/en/index.htm?padre=522. Accessed 13 Jun. 2018.

Kamp, D. van der, McKendry, I., 2010. Diurnal and Seasonal Trends in Convective Mixed-Layer Heights Estimated from Two Years of Continuous Ceilometer Observations in Vancouver, BC. Bound. Lay. Meteorol., 137(3), 459-475. https://doi.org/10.1007/s10546-010-9535-7.

Kim, D.-K., Lee, D.-I., 2015. Atmospheric thickness and vertical structure properties in wintertime precipitation events from microwave radiometer, radiosonde and wind profiler observations. Meteorol. Appl., 22(3), 599-609. https://doi.org/10.1002/met.1494.

Ketterer, C., Zieger, P., Bukowiecki, N., Collaud Coen, M., Maier, O., Ruffieux, D., \& Weingartner, E., 2014. Investigation of the Planetary Boundary Layer in the Swiss Alps Using Remote Sensing and In Situ Measurements. Bound. Lay. Meteorol., 151(2), 317-334. https://doi.org/10.1007/s10546-013-9897-8.

Korhonen, K., Giannakaki, E., Mielonen, T., Pfüller, A., Laakso, L., Vakkari, V., Baars, H., Engelmann, R., Beukes, J. P., Van Zyl, P. G., Ramandh, A., Ntsangwane, L., Josipovic, M., Tiitta, P., Fourie, G., Ngwana, I., Chiloane, K., Komppula, M., 2014. Atmospheric boundary layer top height in South Africa: measurements with lidar and radiosonde compared to three atmospheric models. Atmos. Chem. Phys., 14(8), 4263-4278. https://doi.org/10.5194/acp-14-4263-2014. 
Lyamani, H., Olmo, F. J., Alcántara, A., Alados-Arboledas, L., 2006b. Atmospheric aerosols during the 2003 heat wave in southeastern Spain II: microphysical columnar properties and radiative forcing, Atmos. Environ., 40, 6465-6476.

Lyamani, H., F.J. Olmo, I. Foyo, L. Alados-Arboledas. Black carbon aerosols over an urban area in southeastern Spain: Changes detected after the 2008 economic crisis. Atmospheric Environment, Volume 45, Issue 35, Pages 6423-6432, 2011. http://dx.doi.org/10.1016/j.atmosenv.2011.07.063.

Lyamani, H., Olmo, F. J., Alados-Arboledas, L., 2010. Physical and optical properties of aerosols over an urban location in Spain: seasonal and diurnal variability.Atmos. Chem. Phys., 10, 239-254, doi:10.5194/acp-10-239-2010.

Lyamani, H., Fernández-Gálvez, J. Pérez-Ramírez, D.,Valenzuela, A.,Antón, M., Alados, I., Titos, G., Olmo, F.J., Alados-Arboledas., L., 2012. Aerosol properties over two urban sites in South Spain during an extended stagnation episode in winter season. Atmos. Environ., 62, 424-432.

Morille, Y., Haeffelin, M., Drobinski, P., Pelon, J., 2007. STRAT: An Automated Algorithm to Retrieve the Vertical Structure of the Atmosphere from Single-Channel Lidar Data. J. Atmos. Ocean. Tech., 24(5), 761-775. http://doi.org/10.1175/JTECH2008.1.

Münkel, C., Eresmaa, N., Räsänen, J., Karppinen, A., 2007. Retrieval of mixing height and dust concentration with lidar ceilometer. Bound. Lay. Meteorol., 124, 117-128, doi:10.1007/s10546-006-91033.

Nair, V.S., Moorthy, K.K., Alappattu, D.P., Kunhikrishnan, P.K., George, S., Prabha, R., Nair, P.R., Babu, S.S., Abish, B., Satheesh, S.K., Tripathi, S.C., Niranjan, K., Madhavan, B.L., Srikant, V., Dutt, C.B.S., Badarinath, K.V.S., Reddy, R.R., 2007.Wintertime aerosol characteristics over the Indo-Gangetic Plain (IGP): impacts of local boundary layer processes and long-range transport. J. Geophys. Res. 112, D13205.

Navas-Guzmán, F., Bravo-Aranda, J.A., Guerrero-Rascado, J.L, Granados-Muñoz, M.J, and AladosArboledas, L., 2013. Statistical analysis of aerosol optical properties retrieved by Raman lidar over Southeastern Spain. Tellus B, 65, 21234.

Navas-Guzmán, F., Fernández-Gálvez, J., Granados-Muñoz, M.J, Guerrero-Rascado, J.L., Bravo-Aranda, J.A., and Alados-Arboledas, L., 2014. Tropospheric water vapor and relative humidity profiles from lidar and microwave radiometry. Atmos. Meas. Tech., 7, 1201-1211.

Ortiz-Amezcua, P., Guerrero-Rascado, J.L., Granados-Muñoz, M.J., Bravo-Aranda, J.A., AladosArboledas, L., 2014. Characterization of atmospheric aerosols for a long range transport of biomass burning particles from canadian forest fires over the southern iberian peninsula in july 2013, Optica Pura y Aplicada, 47(1), 43-49.

Ortiz-Amezcua, P., Guerrero-Rascado, J. L., Granados-Muñoz, M. J., Benavent-Oltra, J. A., Böckmann, C., Samaras, S., Stachlewska, I. S., Janicka, Ł., Baars, H., Bohlmann, S., and Alados-Arboledas, L., 2017. Microphysical characterization of long-range transported biomass burning particles from North America at three EARLINET stations, Atmos. Chem. Phys., 17, 5931-5946, doi:10.5194/acp-17-5931-2017. 
1 Pakkanen, T.A., Kerminen, V.M., Ojanena, C.H., Hillamo, R.E., Aarnio, P.,Koskentalo, T., 2000.

2 Atmospheric black carbon in Helsinki. Atmos. Environ. 34, 1497-1506.

3 Pal, S., Behrendt, A. and Wulfmeyer, V., 2010. Elastic-backscatter-lidar-based characterization of the 4 convective boundary layer and investigation of related statistics. Ann Geophys., 28, 825-847.

5 Pal, S., Haeffelin, M., and Batchvarova, E., 2013. Exploring a geophysical process-based attribution 6 technique for the determination of the atmospheric boundary layer depth using aerosol lidar and near7 surface meteorological measurements. J. Geophys. Res-Atmos., 118(16), 9277-9295. 8 https://doi.org/10.1002/jgrd.50710.

9 Pal, S., and Haeffelin, M., 2015. Forcing mechanisms governing diurnal, seasonal, and interannual 10 variability in the boundary layer depths: Five years of continuous lidar observations over a suburban site near Paris. J. Geophys. Res-Atmos., 120, 11,936-11,956, doi:10.1002/2015JD023268.

Papalardo, G., Amodeo, A., Apituley, A., Comeron, A., Freudenthaler, V., Linné, H., Ansmann, A., Bösenberg, J., D'Amico, G., Mattis, I., Mona, L., Wandinger, U., Amiridis, V., Alados-Arboledas, L., Nicolae, D., Wiegner, M., 2014. EARLINET: towards an advanced sustainable European aerosol lidar network. Atmos. Meas. Tech., 7, 2389-2409, doi:10.5194/amt-7-2389-2014.

Patrón, D., Lyamani, H., Titos, G., Casquero-Vera, J.A., Cardell, C., Močnik, G., Alados-Arboledas, L., Olmo, F. J., 2017.Monumental heritage exposure to urban black carbon pollution.Atmos. Environ., 170, 22-32, doi: 10.1016/j.atmosenv.

Petäjä, T., Järvi, L., Kerminen, V.M., Ding, A.J., Sun, J.N., Nie, W., Zilitinkevich, S., 2016. Enhanced air pollution via aerosol-boundary layer feedback in China. Sci. Rep. 6.

Poltera, Y., Martucci, G., Coen, M. C., Hervo, M., Emmenegger, L., Henne, S., Brunner, D., Haefele, A., 2017. PatjfinderTURB: an automatic boundary layer algorithm. Development, validation and application to study the impact on in situ measurements at the Jungfraujoch. Atmos. Chem. Phys., 17, 10051-10070, https://doi.org/10.5194/acp-17-10051-2017.

Rose, T., Creewll, S., Löhnert, U., Simmer, C., 2005 A network suitable microwave radiometer for operational monitoring of cloudy atmosphere. Atmos. Res., 75, 3, 183 - 200.

Schween, J. H., Hirsikko, A., Löhnert, U., Crewell, S., 2014. Mixing-layer height retrieval with ceilometer and Doppler lidar: from case studies to long-term assessment. Atmos. Meas. Tech., 7, 11, p. 3685-3704.

Seidel, D. J., Ao, C. O., Li, K., 2010. Estimating climatological planeratry boundary layer heights from radiosonde observations: Comparison of methods and uncertainty analysis. J. Geophys. Res., 115, D16113, doi:10.1029/2009JD013680.

Spänkuch, D., W. Döhler, J. Güldner, and A. Keens, 1996: Ground-based passive atmospheric remote sounding by FTIR emission spectroscopy_First results with EISAR. Contrib. Atmos. Phys., 69, 97-111. 
1 Steyn, D.G., Baldi, M., Hoff, R.M., 1999. The detection of mixed layer depth and entrainment zone

2 thickness from lidar backscatter profiles. J. Atmos. Ocean. Tech., 16, 953-959.

3 Stachlewska, I. S., Piądłowski, M., Migacz, S., Szkop, A., Zielińska, A. J., Swaczyna, P. L., 2012

4 Ceilometer Observations of the Boundary Layer over Warsaw, Poland. Acta Geophys., Vol. 60, No. 5, $5 \quad 1386-1412$.

6 Stull, R. B., 1988. An Introduction to Boundary Layer Meteorology, vol. 13, Kluwer Academic Publishers, 7 the Netherlands, Dordrecht/Boston/London.

8 Stull, R. B., 2011. Meteorology for Scientists and Engineers, $3^{\text {rd }}$ Edition, Uni. Of British Columbia.

T. Müller, J.S. Henzing, G. De Leeuw, A. Wiedensohler, A. Alastuey, H. Angelov, M. Bizjak, M. Collaud Coen, J.E. Engström, C. Gruening, R. Hillamo, A. Hoffer, K. Imre, P. Ivanow, G. Jennings, J.Y. Sun, N. Kalivitis, H. Karlsson, M. Komppula, P. Laj, S.-M. Li, C. Lunder, A. Marinoni, S. Martins Dos Santos, M. Moerman, A. Nowak, J.A. Ogren, A. Petzold, J.M. Pichon, S. Rodriquez, S. Sharma, P.J. Sheridan, K. Teinilä, T. Tuch, M. Viana, A. Virkkula, E. Weingartner, R. Wilhelm, and Y.Q. Wang. "Characterization and intercomparison of aerosol absorption photometers: Result of two intercomparison workshops". In: Atmospheric Measurement Techniques 4.2 (2011), pp. 245-268. DOI: 10.5194/amt-4-245-2011.

Tang, G., Zhang, J., Zhu, X., Song, T., Münkel, C., Hu, B., Schäfer, K., Liu, Z., Zhang, J., Wang, L., Xin, J., Suppan, P., and Wang, Y.: Mixing layer height and its implications for air pollution over Beijing, China, Atmos. Chem. Phys., 16, 2459-2475, 2016.

Titos, G., Foyo-Moreno, I., Lyamani, H., Querol, X., Alastuey, A., Alados-Arboledas, L., 2012. Optical properties and chemical composition of aerosol particles at an urban location: An estimation of the aerosol mass scattering and absorption efficiencies. J. Geophys. Res-Atmos., 117, D04206, doi:10.1029/2011JD016671.

Titos, G., Jefferson, A., Sheridan, P. J., Andrews, E., Lyamani, H., Alados-Arboledas, L., Ogren, J. A., 2014. Aerosol light-scattering enhancement due to water uptake during the TCAP campaign. Atmos. Chem. Phys., 14, 7031-7043, doi:10.5194/acp-14-7031-7043.

Titos, G., Lyamani, H., Drinovec, L., Olmo, F.J., Mocnik, G., Alados-Arboledas, L., 2015. Evaluation of the impact of transportation changes on air quality. Atmos. Environ. 114,19-31.

Titos, G., Cazorla, A., Zieger, P., Andrews, E., Lyamani, H., Granados- Muñoz, M.J., Olmo, F.j and Alados-Arboledas, L., 2016. Effect of hygroscopic growth on the aerosol light-scattering coefficient: A review of measurements, techniques and error sources. Atmos. Environ., 141, 494-507.

Titos, G., del Águila A., Cazorla, A., Lyamani, H., Casquero-Vera, J.A., Colombi, C., Cuccia, E., Gianelle, V., Alastuey, A., Alasdos-Arboledas, L., 2017. Spatial and temporal variability of carbonaceous aerosols: assessing the impact of biomass burning in the urban environment. Sci. Total Environ., 578, 613-625.

Tsaknakis, G., Papayannis, A., Kokkalis, P., Amiridis, V., Kam- bezidis, H. D., Mamouri, R. E., Georgoussis, G., Avdikos, G., 2011. Inter-comparison of lidar and ceilometer retrievals for aerosol and 
1 Planetary Boundary Layer profiling over Athens, Greece. Atmos. Meas. Tech., 4, 1261-1273, 2 doi:10.5194/amt-4-1261-2011.

3 Uzan, L., Egert, S., Alpert, P., 2016. Ceilometer evaluation of the eastern Mediterranean summer boundary 4 layer height - first study of two Israeli site., Atmos. Meas. Tech., 9, 4387-4398, doi:10.5194/amt-9-438752016

6 Vaisala Oyj: BL-Matlab User’s Guide v0.98. Vaisala Oyj, Helsinki, Finland, 2011.

7 van Baelen, J., Aubagnac J. P., Dabas, A., 2005.Comparison of near-real time estimates of integrated water 8 vapor derived with GPS, radiosondes, and microwave radiometer. J. Atmos. Ocean. Tech., 22, 201-210. van der Kamp, D., and I. McKendry, 2010. Diurnal and seasonal trends in convective mixed-layer heights estimated from two years of continuous ceilometer observations in Vancouver, BC. Bound. Lay. Meteorol., $137,459-475$.

Valenzuela, A., Olmo, F. J., Lyamani, H., Granados-Muñoz, M. J., Antón, M., Guerrero-Rascado, J. L., Quirantes, A., Toledano, C., Perez-Ramírez, D., Alados-Arboledas, L., 2014. Aerosol transport over the western Mediterranean basin: Evidence of the contribution of fine particles to desert dust plumes over alborán island. J. Geophys. Res., 119, 24, 14,028-14,044.

Wagner, P., Schäfer, K., 2017. Influence of mixing layer height on air pollutant concentrations in an urban street canyon. Urban Climate, 22, 64-79 doi: 10.1016/j.uclim.2015.11.001.

Zhao, D., Xin, J., Gong, C., Quan, J., Liu, G., Zhao, W., Wang, Y., Liu, Z., Song, T., 2019. The formation mechanism of air pollution episodes in Beijing city: Insights into the measured feedback between aerosol radiative forcing and the atmospheric boundary layer stability. Sci. Total Environ., 692, pp. 371381, doi:10.1016/j.scitotenv.2019.07.255.

Zhu, X., Tang, G., Hu, B., Wang, L., Xin, J., Zhang, J., Liu, Z., Munkel, C., Wang, Y., 2016. Regional pollution and its formation mechanism over North China Plain: A case study with ceilometer observation and model simulations. J. Geophys. Res. Atmos., 121, 14,574-14,588, doi:10.1002/ 2016JD025730.

Zhu, X., Tang, G., Guo, J., Hu, B., Song, T., Wang, L., Xin, J., Gao, W., Münkel, C., Schäfer, K., Li, X., Wang, Y., 2018a. Mixing layer height on the North China Plain and meteorological evidence of serious air pollution in southern Hebei, Atmos. Chem. Phys., 18, 4897-4910, https://doi.org/10.5194/acp-18-48972018.

Zhu, X., Tang, G., Lv, F., Hu, B., Cheng, M., Munkel, C., Schafer, K., Xin, J., An, X., Wang, G., Li, X., Wang, Y., 2018b. The spatial representativeness of mixing layer height observations in the North China Plain. Atmos Res 209:204-211. 


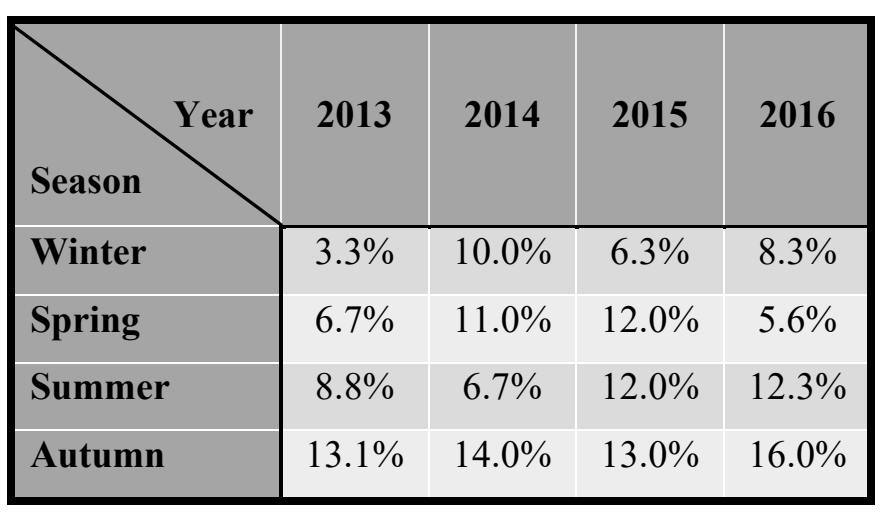

18

Table 1 - Percentage of removed profiles due to quality control 


\begin{tabular}{|l|c|c|c|c|c|}
\hline Year & $\begin{array}{r}\mathbf{2 0 1 2} \\
(\mathbf{1 0 0} \%)\end{array}$ & $\begin{array}{r}\mathbf{2 0 1 3} \\
\mathbf{( 8 7 \% )}\end{array}$ & $\begin{array}{r}\mathbf{2 0 1 4} \\
\mathbf{( 7 7 \% )}\end{array}$ & $\begin{array}{r}\mathbf{2 0 1 5} \\
\mathbf{( 7 0 \% )}\end{array}$ & $\begin{array}{c}\mathbf{2 0 1 6} \\
\mathbf{( 7 0 \% )}\end{array}$ \\
\hline Weason (*) & & & & & \\
\hline Spring & $94 \%$ & $83 \%$ & $86 \%$ & $86 \%$ & $90 \%$ \\
\hline Summer & $83 \%$ & $85 \%$ & $84 \%$ & $88 \%$ & $83 \%$ \\
\hline Autumn & $81 \%$ & $76 \%$ & $77 \%$ & $64 \%$ & $73 \%$ \\
\hline
\end{tabular}




\begin{tabular}{|c|c|c|c|c|c|}
\hline $\begin{array}{l}\text { Measurement } \\
\text { Site }\end{array}$ & Granada & $\begin{array}{c}\text { Highveld } \\
\text { (Korhonen et al. 2014) }\end{array}$ & $\begin{array}{c}\text { Paris } \\
(\text { Pal et al. , 2015) }\end{array}$ & $\begin{array}{c}\text { Jülich } \\
\text { (Schween et al. , 2014) }\end{array}$ & $\begin{array}{c}\text { Leipzig } \\
\text { (Baars et al., 2008) }\end{array}$ \\
\hline Localization & $\begin{array}{c}37.16^{\circ} \mathrm{N} \\
3.61^{\circ} \mathrm{W}\end{array}$ & $26^{\circ} 15^{\prime} \mathrm{S}, 29^{\circ} 26^{\prime} \mathrm{E}$ & $48.713^{\circ} \mathrm{N}, 2.208^{\circ} \mathrm{E}$ & $50^{\circ} 54^{\prime} \mathrm{N}, 6^{\circ} 24^{\prime} \mathrm{E}$ & $51.3^{\circ} \mathrm{N}, 12.4^{\circ} \mathrm{E}$ \\
\hline $\begin{array}{l}\text { Altitude } \\
\text { (m a.s.l.) }\end{array}$ & 680 & 1745 & 160 & 111 & 113 \\
\hline Instrument & MWR & Polly ${ }^{\mathrm{XT}}$ & $\begin{array}{l}\text { Aerosol lidar and } \\
\text { meteorological } \\
\text { station }\end{array}$ & Doppler lidar & Polly \\
\hline Algorithm & $\begin{array}{l}P M \text { and } \\
T G M\end{array}$ & $\begin{array}{c}\text { Wavelet Covariance } \\
\text { Transform }\end{array}$ & STRAT+ & $\begin{array}{c}\text { Variance of vertical wind } \\
\text { speed }\end{array}$ & $\begin{array}{l}\text { Wavelet Covariance } \\
\text { Transform }\end{array}$ \\
\hline
\end{tabular}

Table 3 - Localization of the different sites and instrumentations as well as methods used for $P B L$ characteristics determination. 


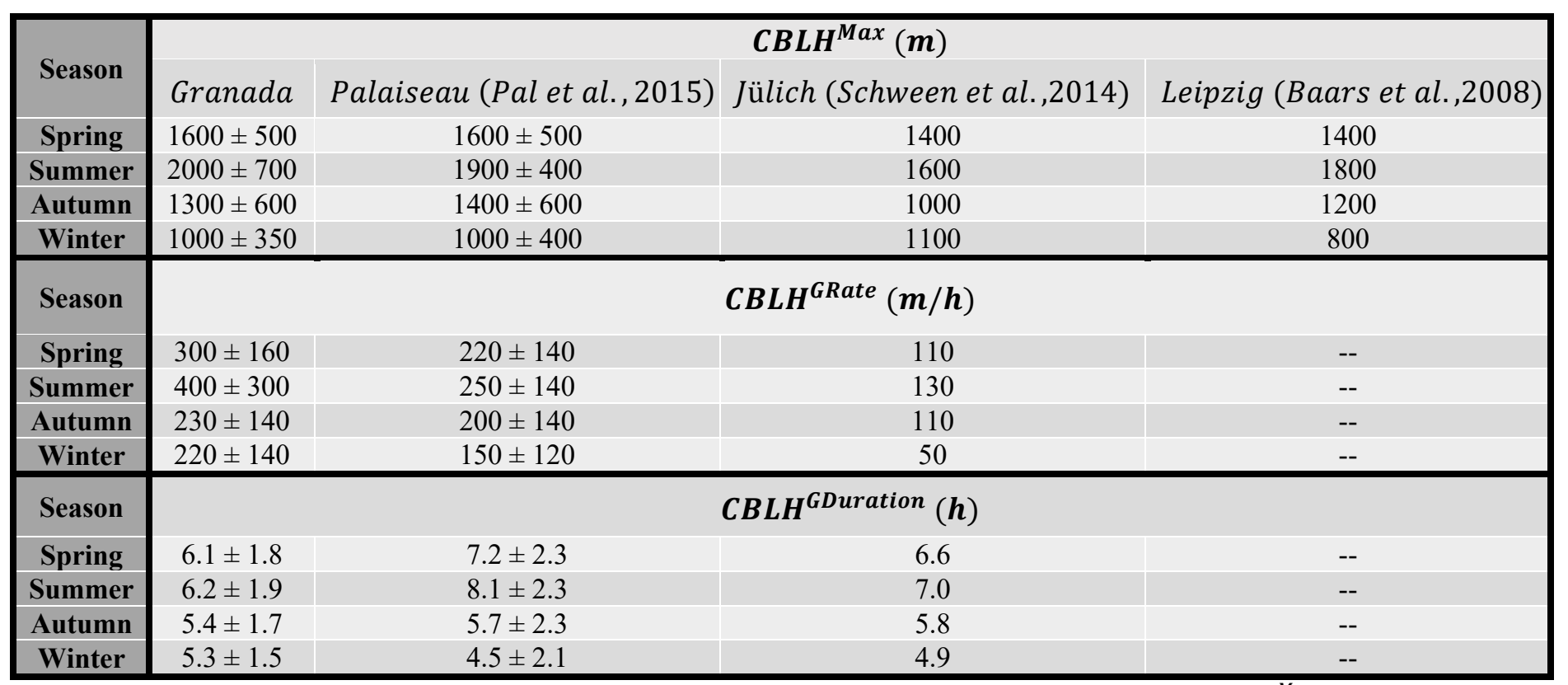

15 Table 4 - Seasonal mean values ( \pm standard deviation) of Maximum of convective boundary layer height $\left(C B L H^{\operatorname{Max}}\right)$,

16 convective boundary layer height growth rate $\left(C B L H^{\text {GRate }}\right)$ and convective boundary layer growth duration

$17\left(\right.$ CBLH $\left.H^{\text {GDuration }}\right)$ obtained at Granada, Palaiseau, Jülich and Leipzig. 


\begin{tabular}{|l|c|c|c|c|}
\hline \multicolumn{1}{|c|}{ Year } & $\begin{array}{c}\mathbf{2 0 1 3} \\
(\mathbf{9 9 . 7 \% )}\end{array}$ & $\begin{array}{c}\mathbf{2 0 1 4} \\
\mathbf{( 1 0 0 . 0 \% )}\end{array}$ & $\begin{array}{c}\mathbf{2 0 1 5} \\
\mathbf{( 1 0 0 . 0 \% )}\end{array}$ & $\begin{array}{c}\mathbf{2 0 1 6} \\
\mathbf{( 9 6 . 2 \% )}\end{array}$ \\
\hline Winter & $96.7 \%$ & $51.1 \%$ & $84.4 \%$ & $67.8 \%$ \\
\hline Spring & $46.7 \%$ & $50.0 \%$ & $50.0 \%$ & $45.6 \%$ \\
\hline Summer & $34.4 \%$ & $56.7 \%$ & $50.0 \%$ & $32.2 \%$ \\
\hline Autumn & $27.8 \%$ & $42.2 \%$ & $56.7 \%$ & $21.1 \%$ \\
\hline
\end{tabular}

Table 5 - Ceilometer recovery rate

* Measurement days 

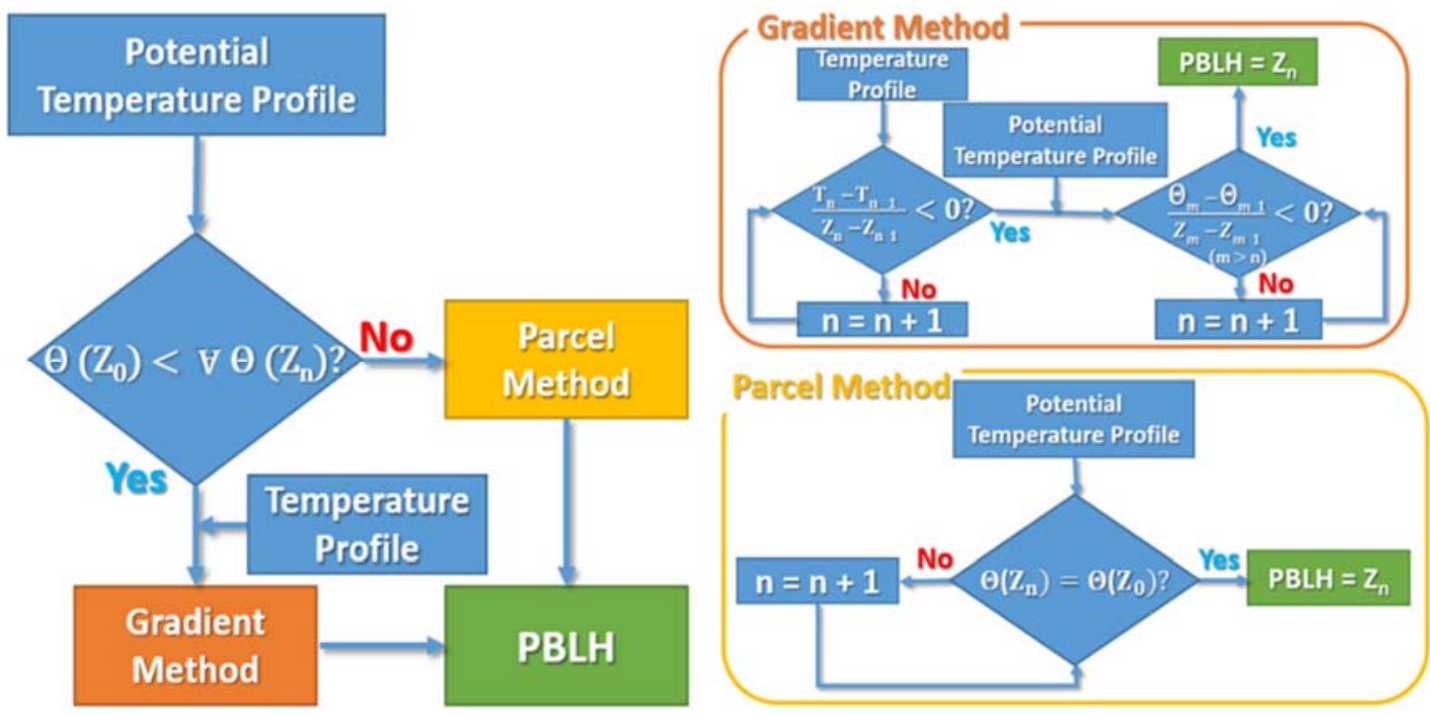

Figure 1 - Combination of two methods to detect $P B L H$ based on Temperature Profile. 

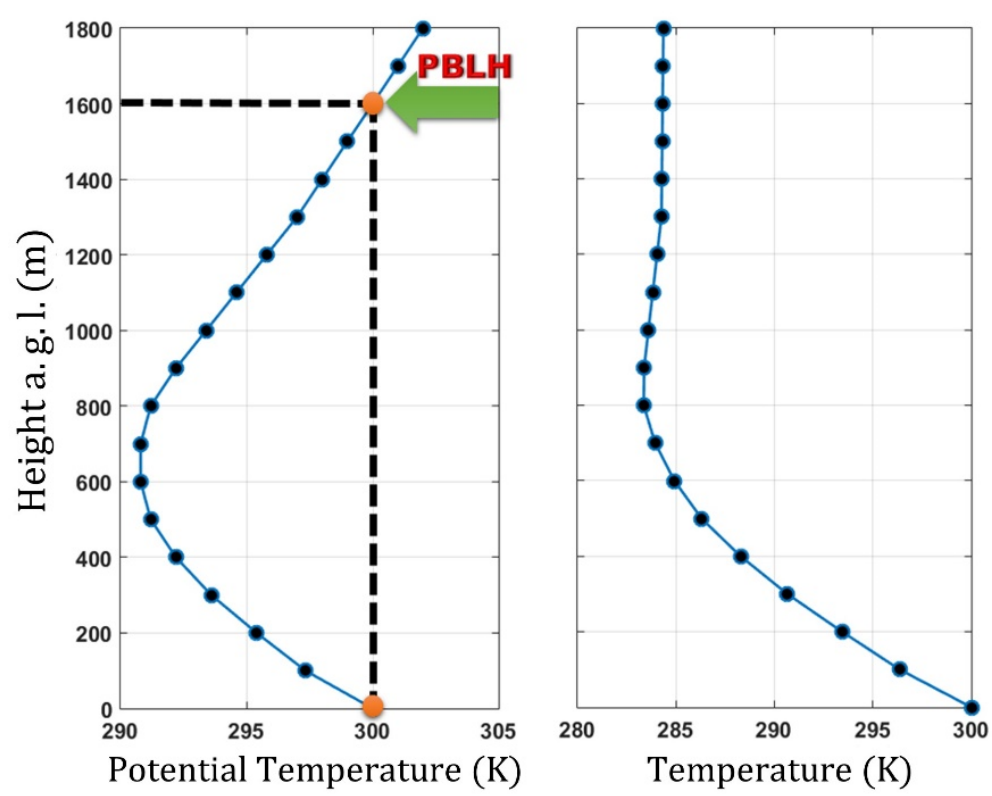

Figure 2 - Determination of $P B L H$ by Parcel Method. Potential Temperature (left) and Temperature (right) 


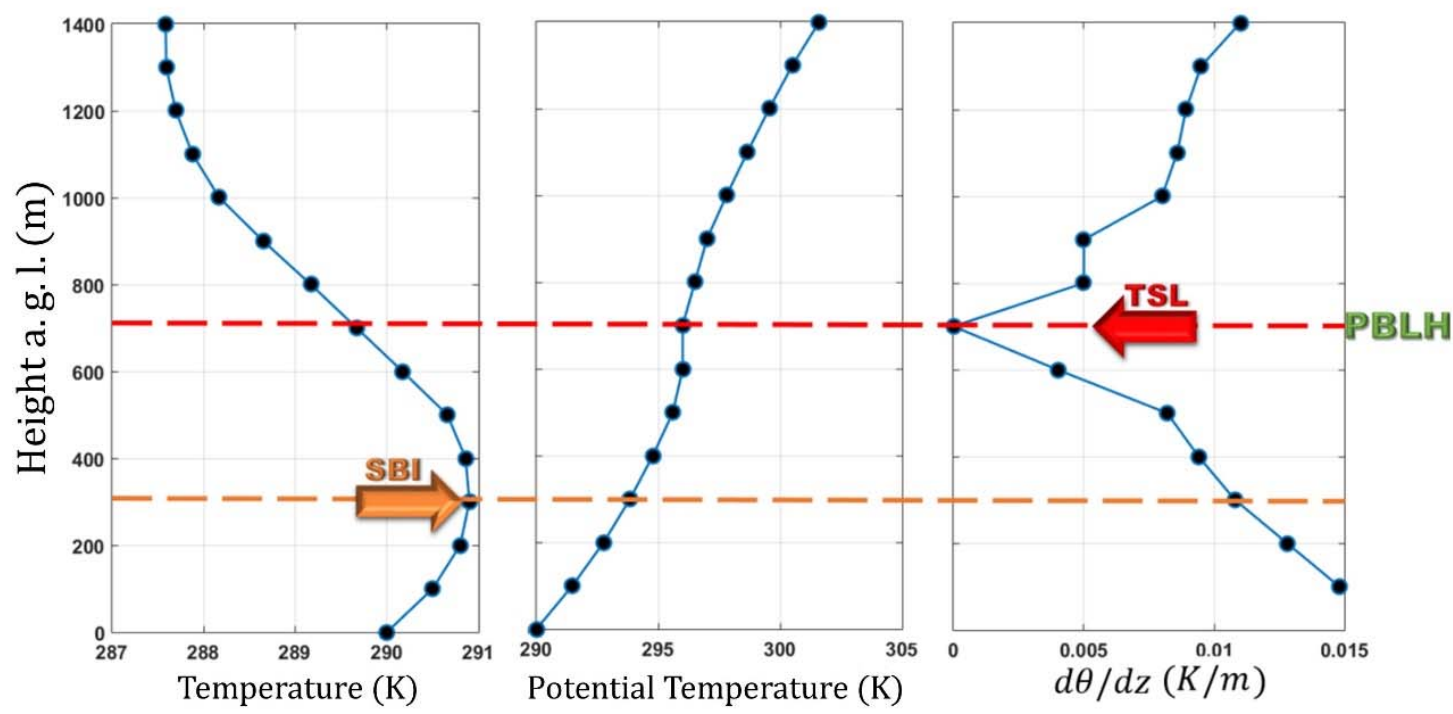

Figure 3- Detection of $P B L H$ by Temperature Gradient Method from SBI and TSL height. Temperature (left), Potential Temperature (center) and Gradient of Potential Temperature (right). 


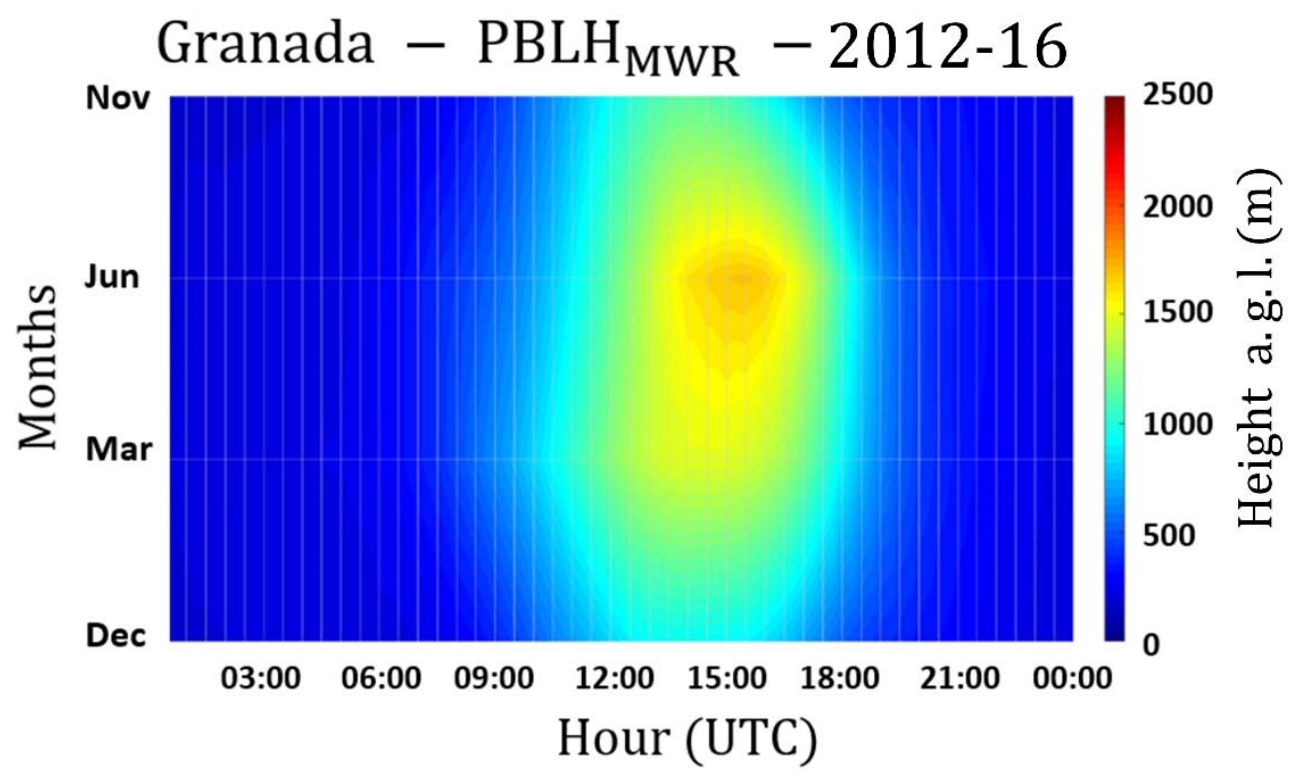

Figure 4 - Average daily $P B L H_{M W R}$ since 2012 until 2016. 

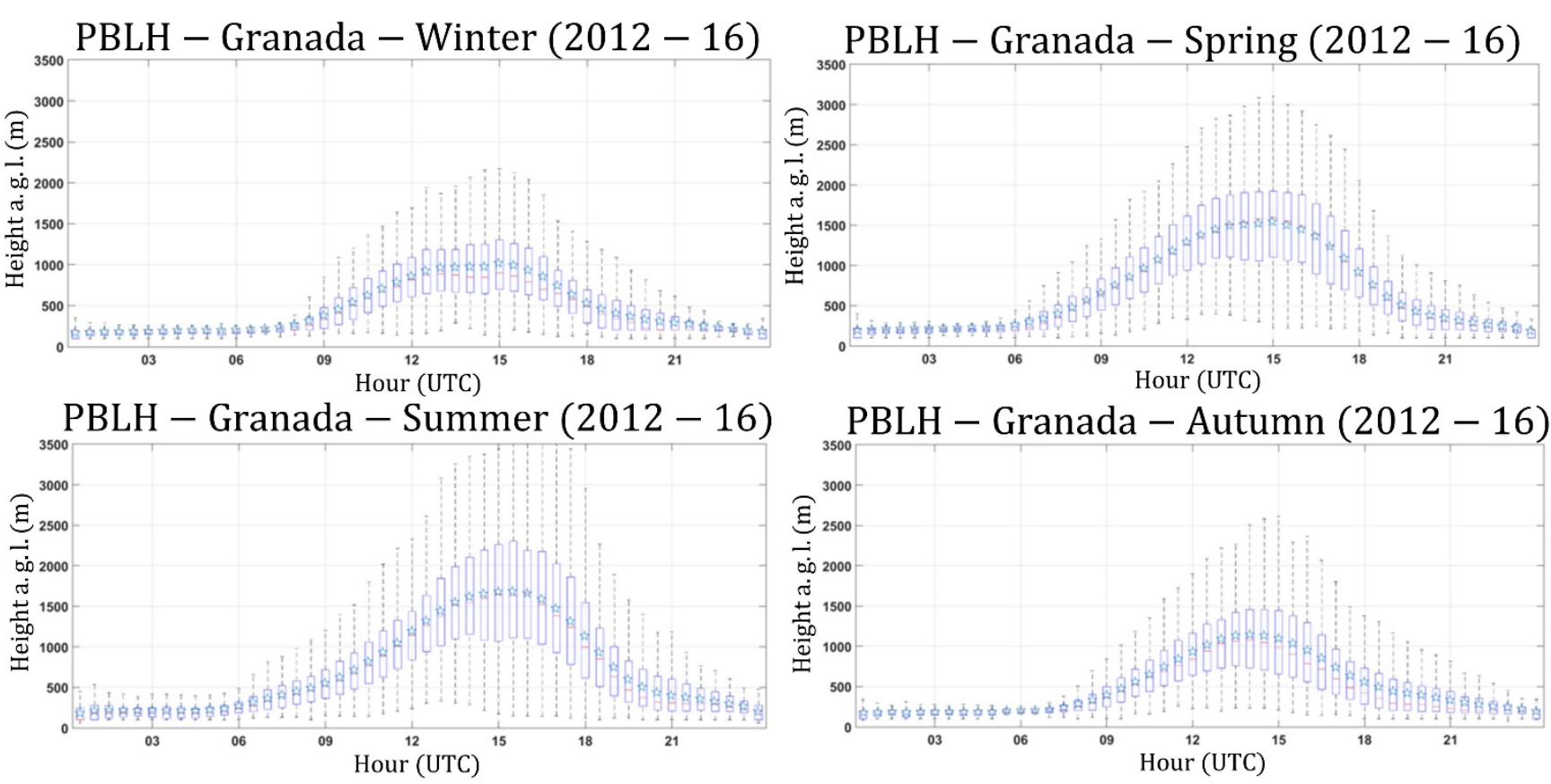

Figure 5 - Daily $P B L H_{M W R}$ cycle for winter (DJF), spring (MAM), summer (JJA) and autumn (SON) since 2012 until 2016. Whiskers and boxes indicate 10, 25, 75 and $90 \%$ percentiles. The red lines represent the median and the blue stars indicate the mean. 


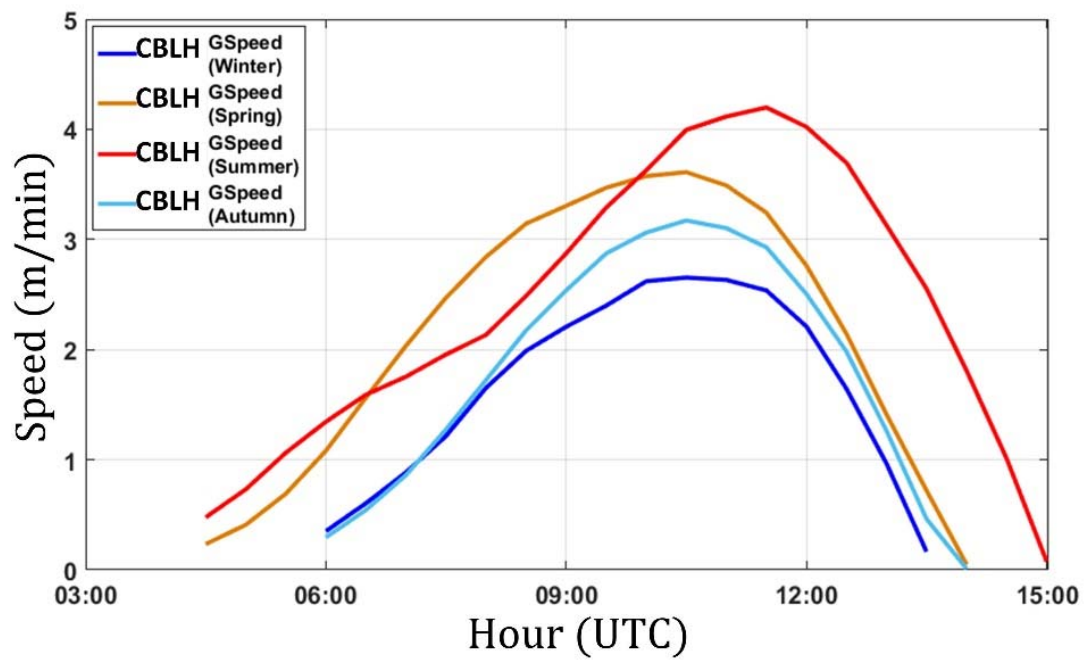

Figure 6 - CBLH Growth Speed (CBLH ${ }^{G S p e e d}$ ) for winter (DJF-blue line), spring (MAM - orange line), summer (JJA - red line) and autumn (SON - light blue line). 
Maximum of CBLH - Granada - Winter

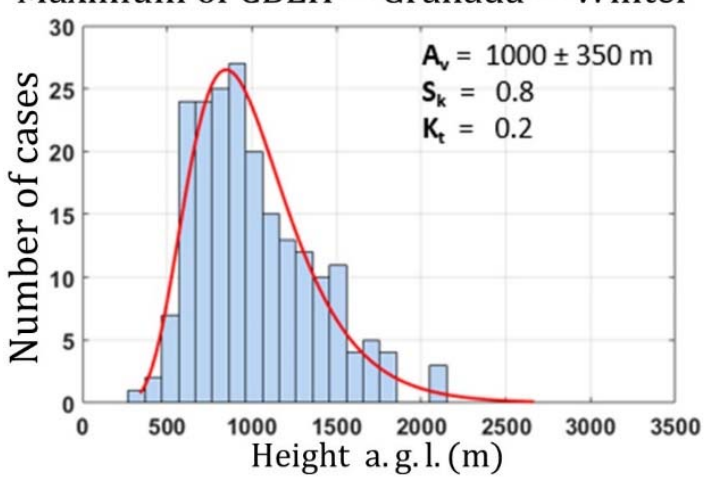

Maximum of CBLH - Granada - Summer

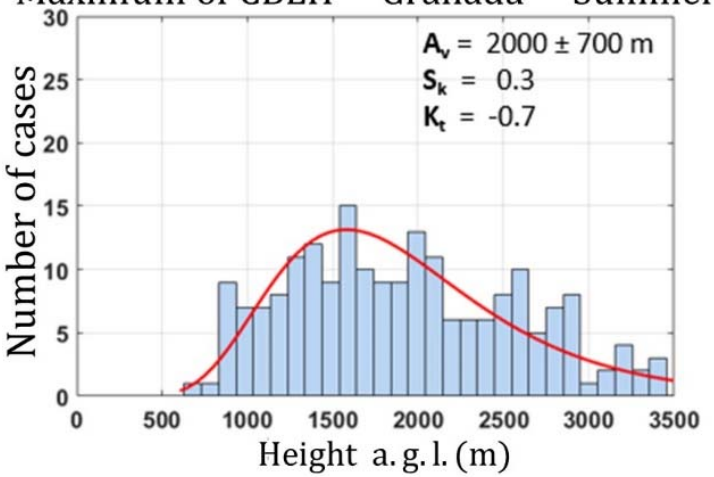

Maximum of CBLH - Granada - Spring

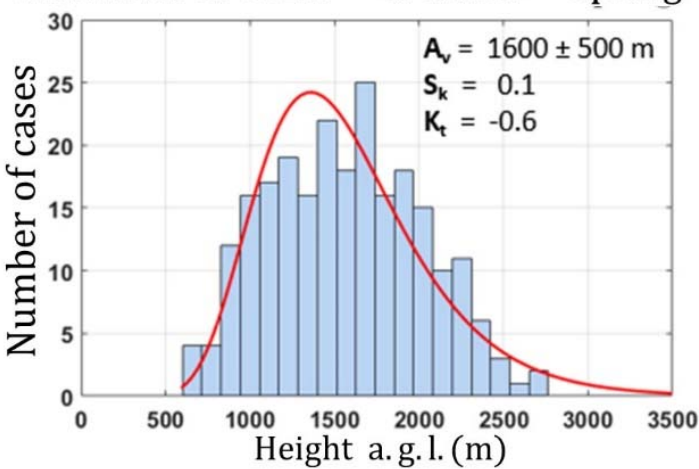

Maximum of CBLH - Granada - Autumn

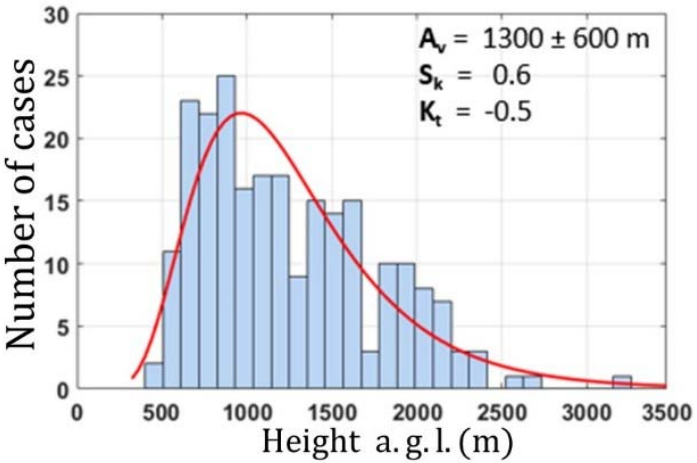

Figure $7-C B L H_{M W R}^{M a x}$ frequency for winter (DJF), spring (MAM), summer (JJA) and autumn (SON) since 2012 until 2016. Each bin size is equivalent to $100 \mathrm{~m}$. The red line indicates a lognormal distribution. $A_{v}, S_{k}$ and $K_{t}$ represent the average, skewness and kurtosis values, respectively. 


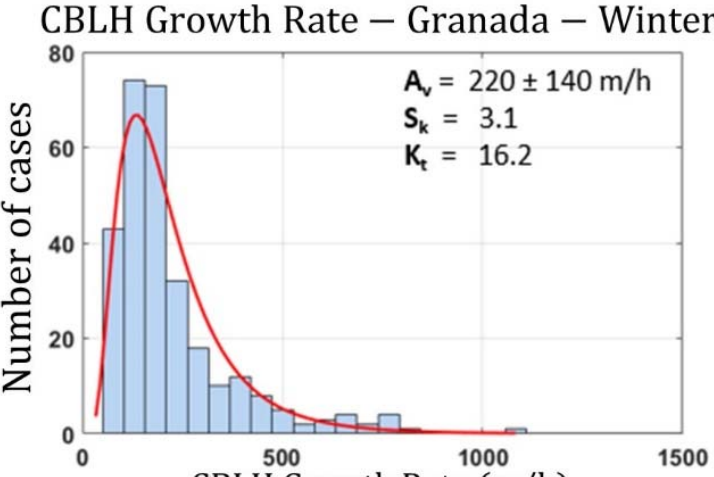

CBLH Growth Rate (m/h)
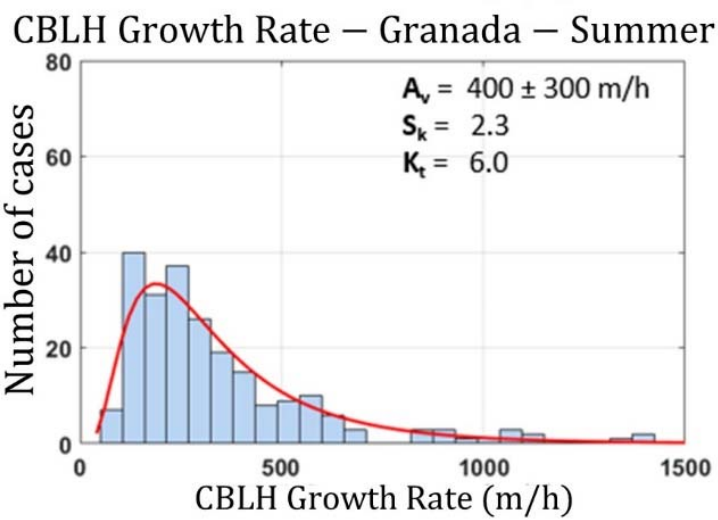

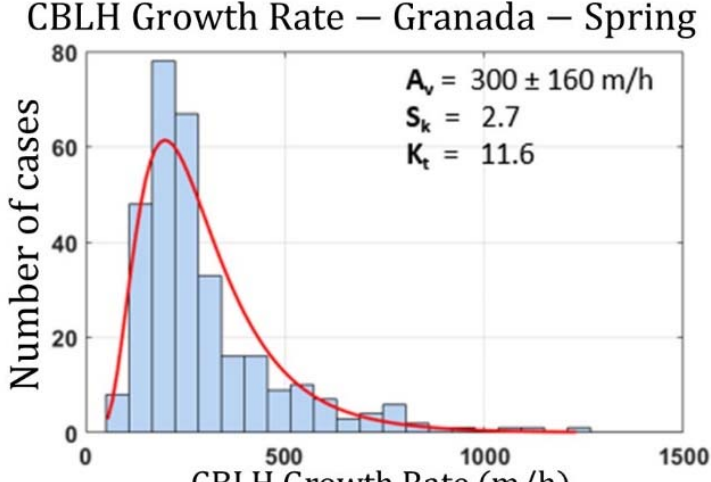

CBLH Growth Rate $(\mathrm{m} / \mathrm{h})$

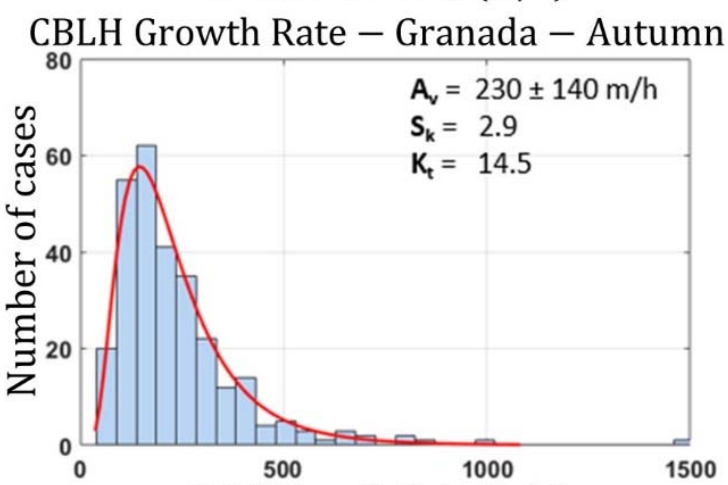

CBLH Growth Rate (m/h)

Figure 8-CBLH $H_{M W R}^{G R a t e}$ frequency for winter (DJF), spring (MAM), summer (JJA) and autumn (SON) since 2012 until 2016. Each bin size is equivalent to $100 \mathrm{~m}$. The red line indicates a lognormal distribution. $A_{v}, S_{k}$ and $K_{t}$ represent the average, skewness and kurtosis values, respectively. 

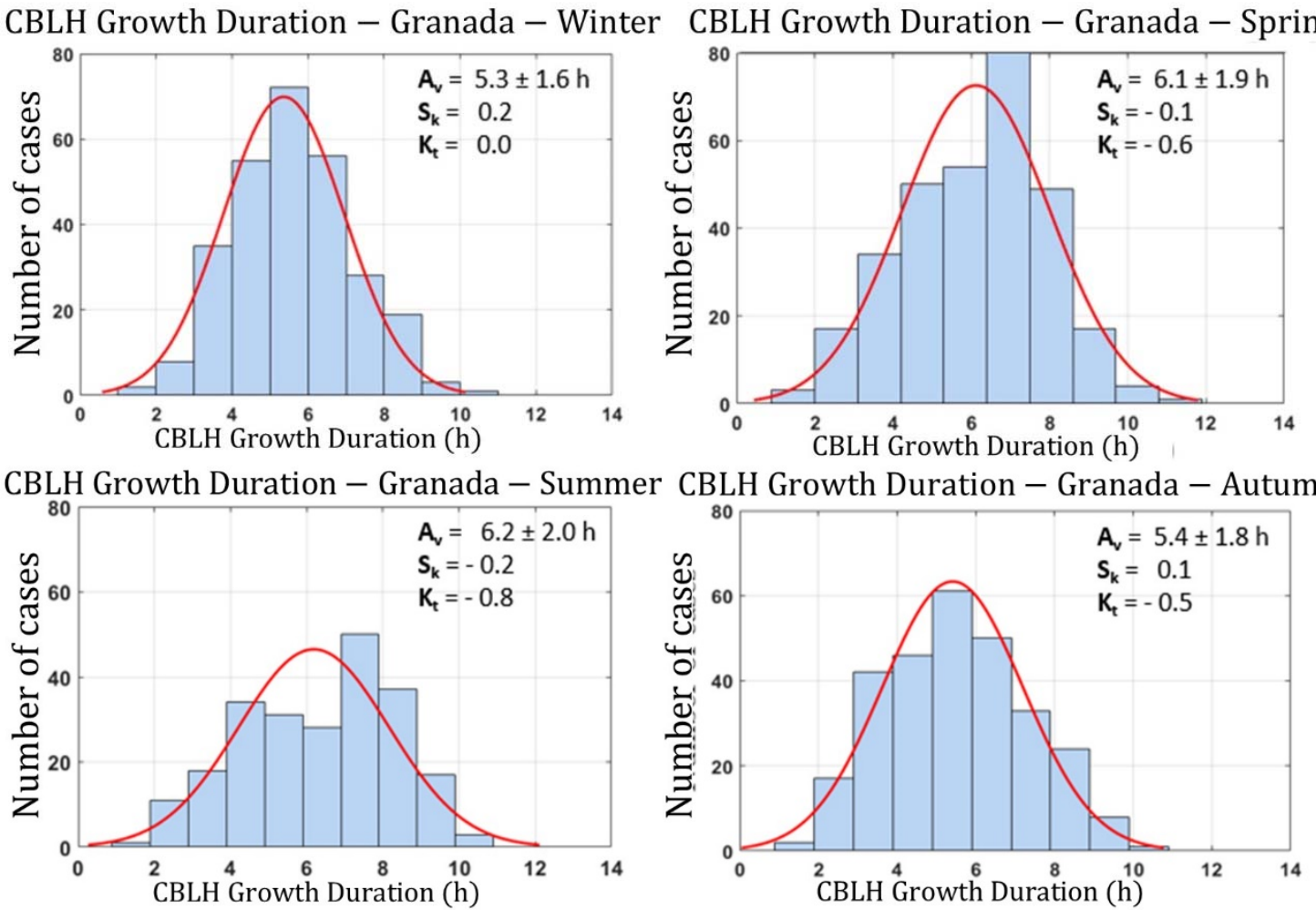

Figure $9-C B L H_{M W R}^{G D u r}$ frequency for winter (DJF), spring (MAM), summer (JJA) and autumn (SON) since 2012 until 2016. Each bin size is equivalent to $100 \mathrm{~m}$. The red line indicates a lognormal distribution. $A_{v}, S_{k}$ and $K_{t}$ represent the average, skewness and kurtosis values, respectively. 

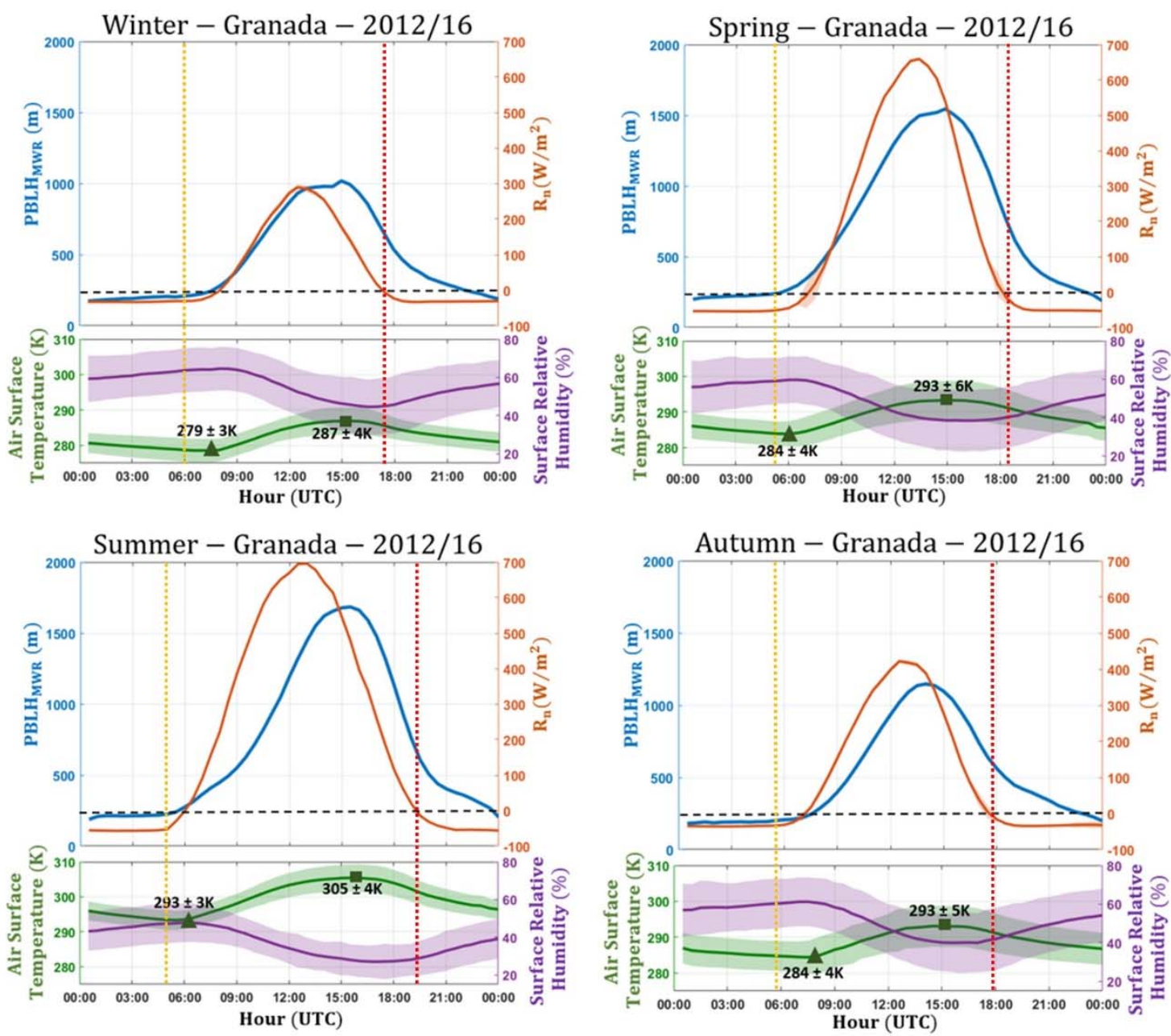

Figure 10 - Comparison among average seasonal daily cycle of $P B L H_{M W R}$ (blue line), $R_{n}$ (orange line), surface air temperature (green line) and surface relative humidity (purple line) for all meteorological seasons from 2012 until 2016. The dotted yellow and red lines represent the average hour of sunrise and sunset, respectively, of each season. 

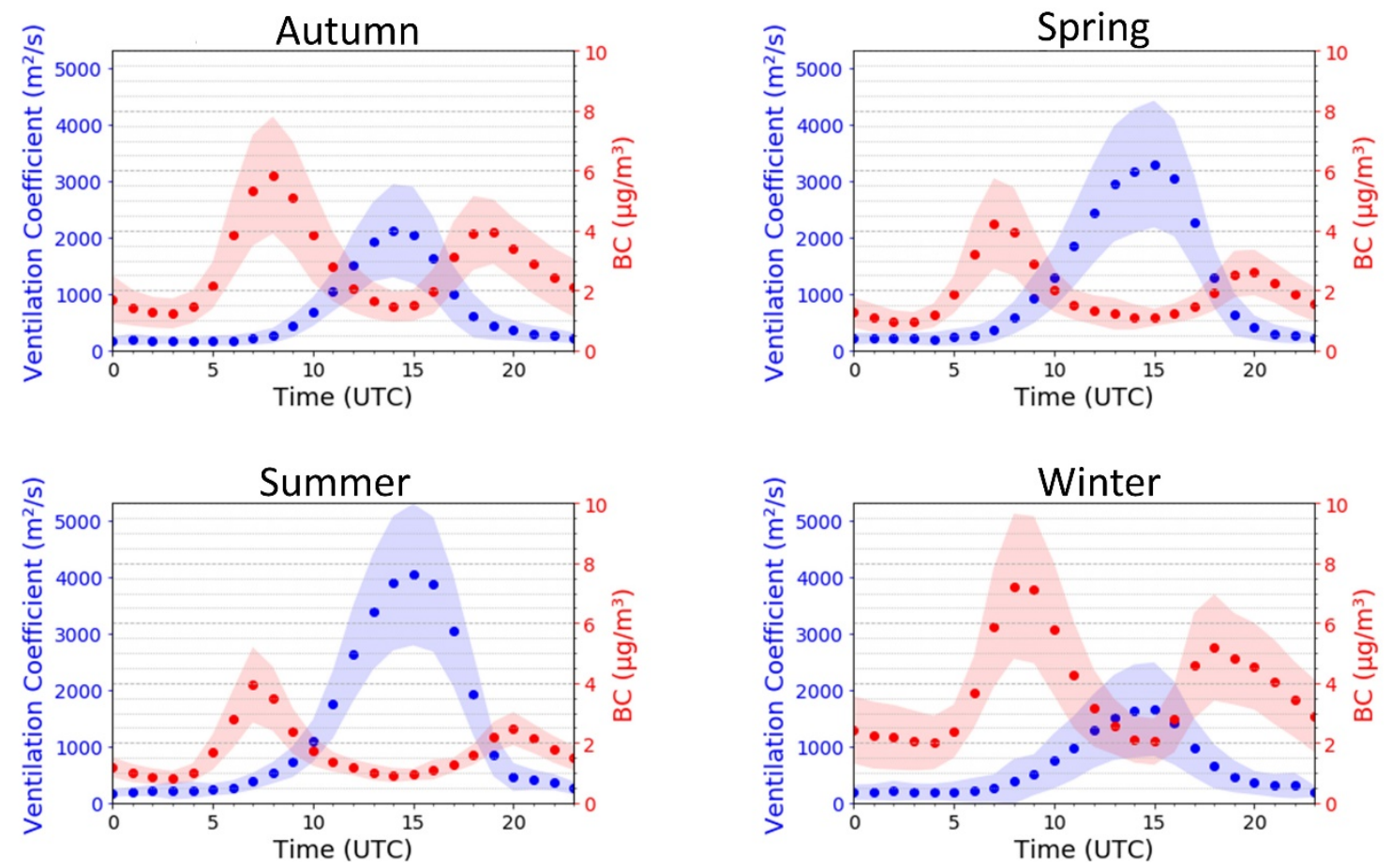

Figure 11 - Seasonal daily cycle of Ventilation Coefficient $[V C]$ (blue line), and Black Carbon $[B C]$ concentration (red line) for 2012-2016. 

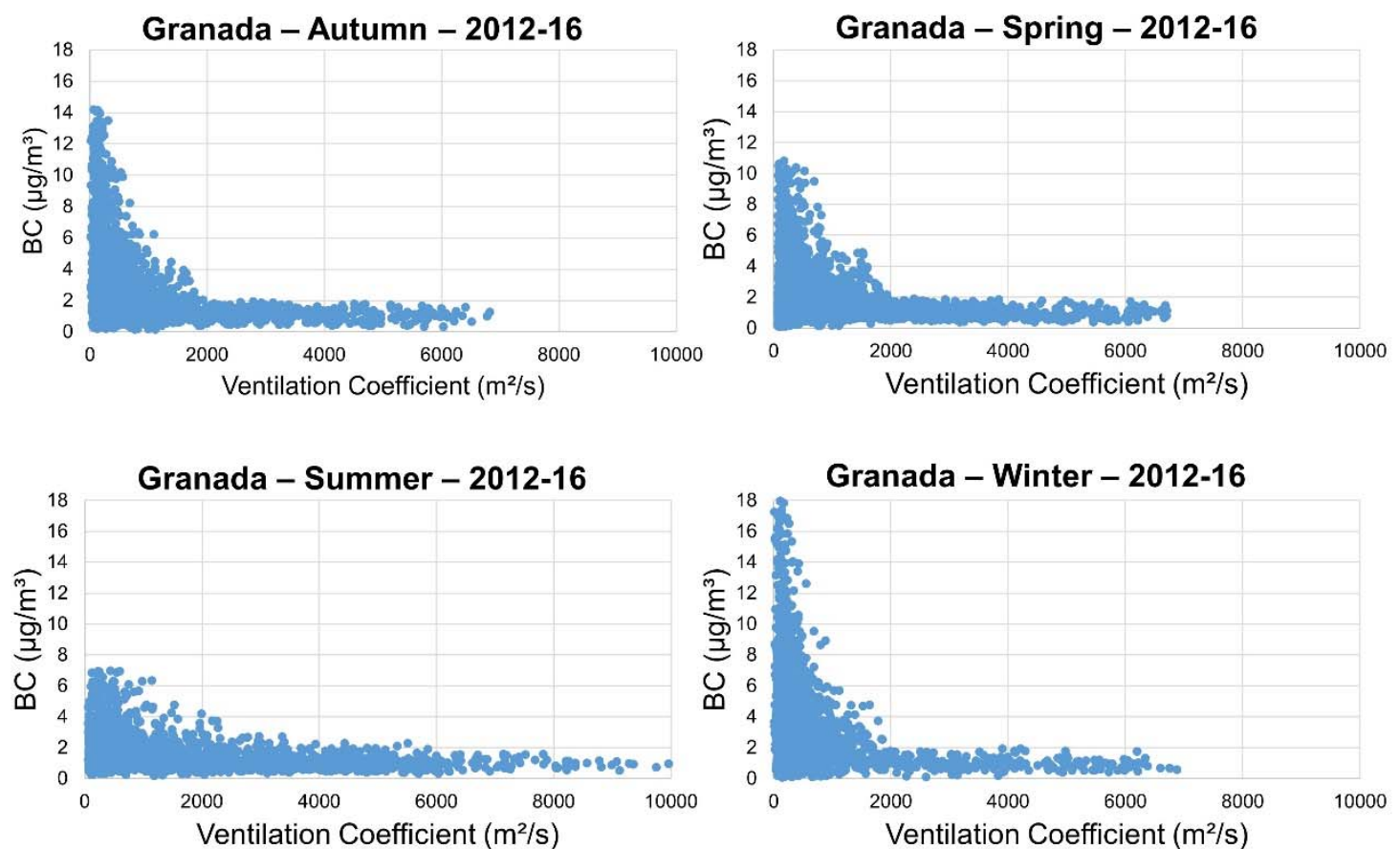

Figure $12-B C$ concentration versus Ventilation Coefficient for winter (DJF), spring (MAM), summer (JJA) and autumn (SON) for 2012-2016. 
9

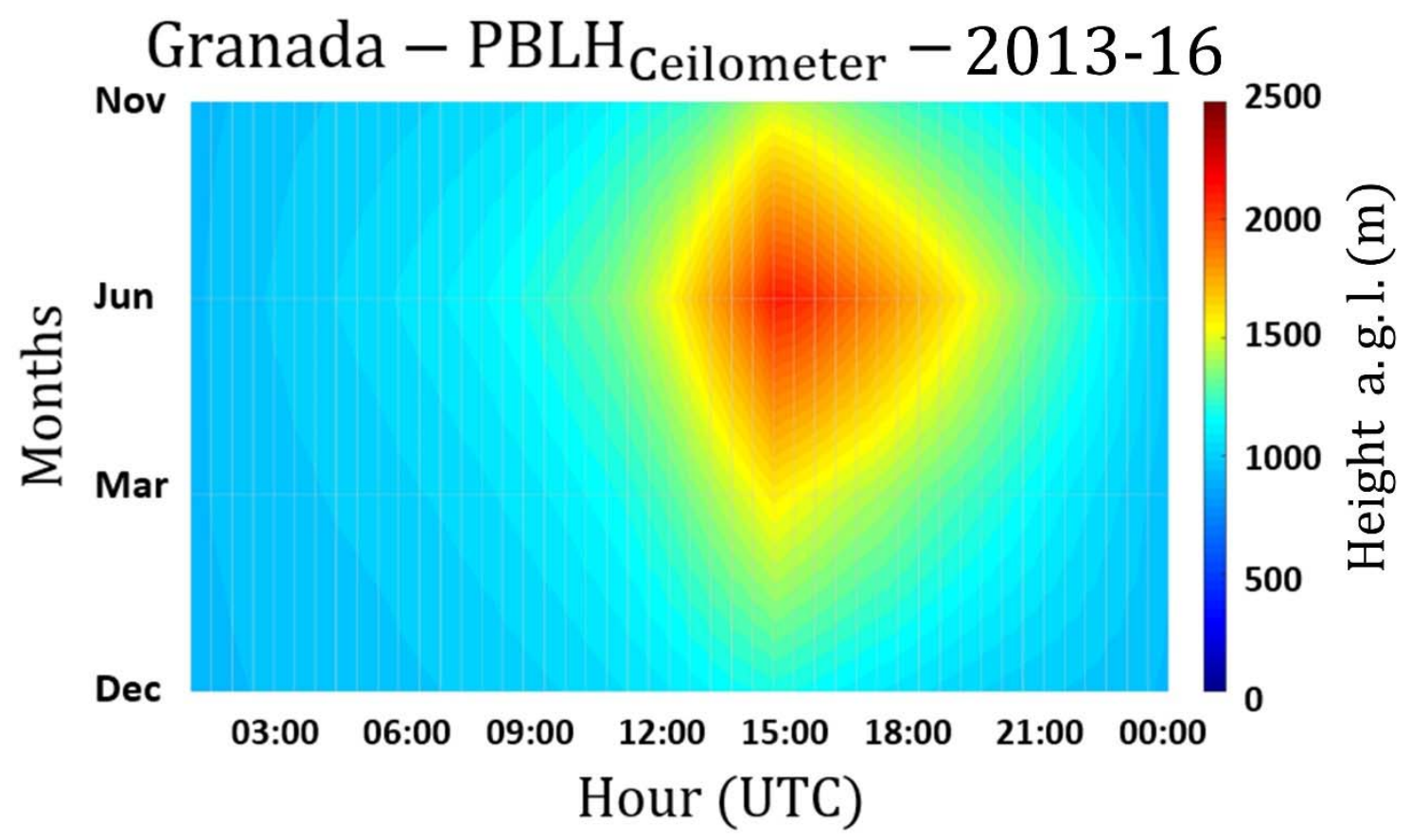

Figure 13 - Average daily PBLH $H_{\text {Ceilometer }}$ since 2013 until 2016. 
10
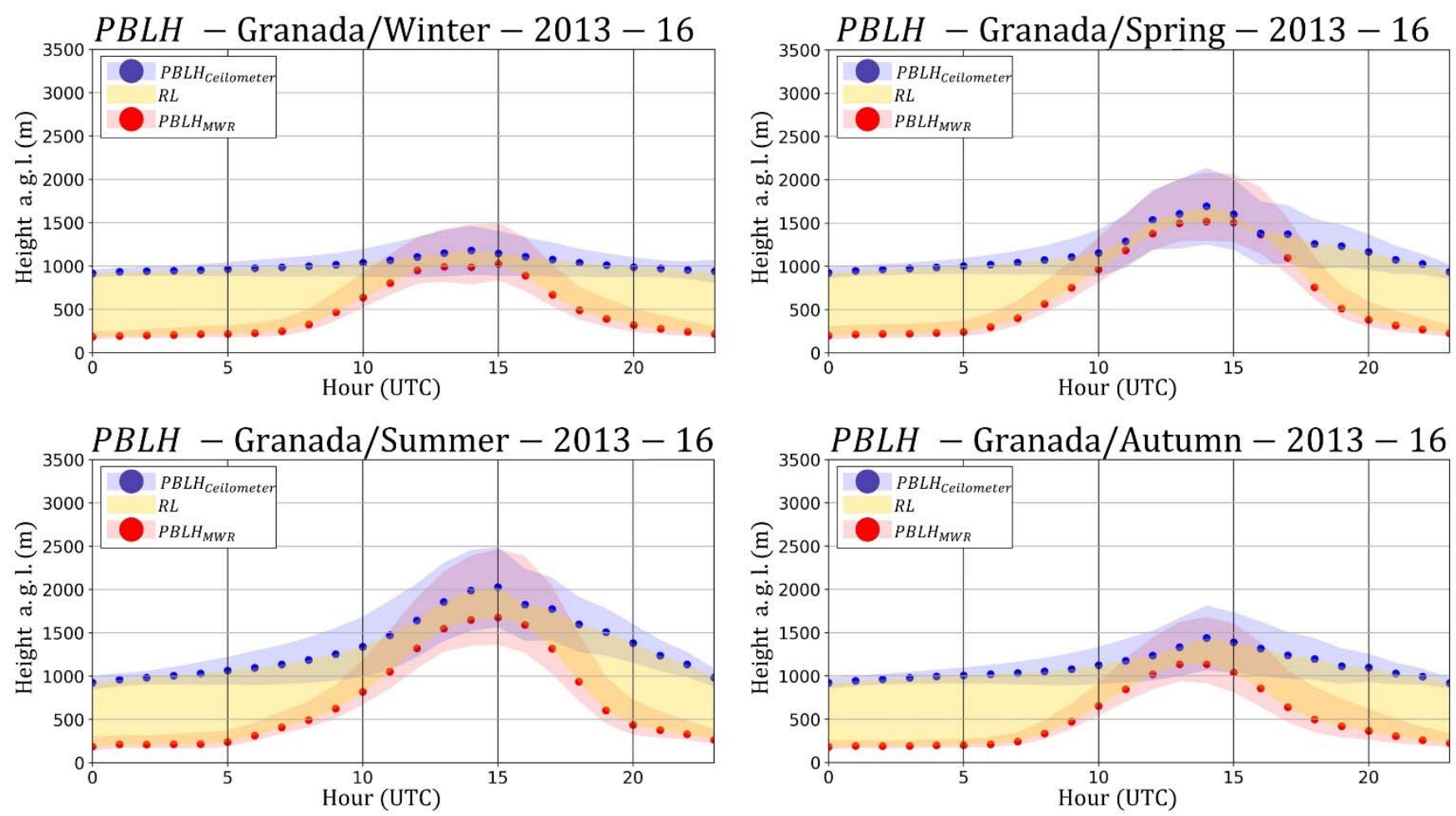

Figure 14 - Comparison between $P B L H_{M W R}$ (red dots) and $P B L H_{\text {Ceilometer }}$ (blue dots) since 2013 until 2016. The yellow region represents the $R L$ thickness.

11

12

13

14 